\title{
14. CORRELATION OF CALCAREOUS NANNOPLANKTON AND PLANKTONIC FORAMINIFER BIOSTRATIGRAPHY OFF THE COAST OF SOUTHERN CHILE ${ }^{1}$
}

\author{
Dorothee Spiegler ${ }^{2}$ and Carla Müller ${ }^{3}$
}

\begin{abstract}
The biostratigraphy established for ODP Leg 141 Sites 859 through 863, drilled off the coast of southern Chile, is based mainly on calcareous nannoplankton and planktonic foraminifers. Because of the scarcity of the fossils and the low diversity of the assemblages, the biostratigraphic resolution is quite low. The uppermost sediments contain well-preserved fossil assemblages that indicate warm surface water influences at the southern mid-latitudes. The oldest sediments may belong to the uppermost lower Pliocene. The Pliocene/Pleistocene boundary is determined by the first occurrence of the Gephyrocapsa oceanica group at 1.6 Ma.
\end{abstract}

\section{INTRODUCTION}

Five sites were drilled during the Ocean Drilling Program (ODP) Leg 141 on the Chile margin in the vicinity of the Nazca/Antarctica/ South America Plate Triple Junction (Fig. 1). Sites 859, 860, and 861 are located on a west-east transect across the accretionary complex at different water depths. Site 862 was drilled near the crest of the Taitao Ridge of oceanic origin, and Site 863 was drilled at the base of the trench slope of the Chile Trench at the point where the Chile Ridge is being subducted.

The biostratigraphy for these sites is based mainly on results from calcareous nannoplankton and planktonic foraminifer investigations obtained from the same samples.

In general, the foraminifers, the nannoplankton assemblages as well as the siliceous microfossils are of low species diversity as a result of low water temperatures, dissolution, and dilution by detrital material. Thus, the biostratigraphic resolution is poor. Observed fluctuations in the abundance and diversity of the fossil assemblages may be related to climatic changes.

\section{METHODS}

Samples were taken from the core catchers and about one sample per section of core. The preparation methods used to obtain foraminifers differed depending on the degree of sediment induration. Soft sediments were washed over a $63 \mu \mathrm{m}$ screen. Slightly indurated sediments were soaked in diluted $\mathrm{H}_{2} \mathrm{O}_{2}$ solution and then washed. Indurated samples were freeze-dried, soaked in hot paraffin, and boiled in a soda lye until disintegration occurred. This method was repeated until a reasonable amount of loose particles was obtained. After the washed samples were dried, the fossils were separated under the binocular microscope. The planktonic/benthic ratios were calculated. The state of preservation of planktonic foraminifers is described as follows: $\mathrm{G}=$ good (little or no fragmentation, overgrowth, and/or dissolution); $\mathrm{M}=$ moderate (some signs of fragmentation, overgrowth, and/or dissolution); $\mathrm{P}=$ poor (severe fragmentation, heavy overgrowth, and/or dissolution). Samples with reworked foraminifers sometimes in different colors, translucent-white and yellow-orange, are marked in the tables as $c$. Deformed specimens of foraminifers are

\footnotetext{
'Lewis, S.D., Behrmann, J.H., Musgrave, R.J., and Cande, S.C. (Eds.), 1995. Proc. ODP, Sci. Results, 141: College Station, TX (Ocean Drilling Program).

${ }^{2}$ GEOMAR Research Center for Marine Geosciences, Wischhofstrasse 1-3, D-24148 Kiel, Federal Republic of Germany,

${ }^{3}$ Institute of Geology and Paleontology of the Johann-Wolfgang-Goethe University, Senckenberg-Anlage 32-43, D-60325 Frankfurt/Main, Federal Republic of Germany.
}

indicated as $d$ and partly silicified ones as $s$. The abundances of foraminifers and nannofossils given in the range charts are based on semiquantitative estimate $(B=$ barren, $T=$ traces, $R=$ rare, $F=$ few, $\mathrm{C}=$ common, $\mathrm{A}=$ abundant). Smear slides were prepared for the investigation of calcareous nannoplankton. The samples were studied using a polarizing microscope.

\section{BIOSTRATIGRAPHY}

\section{Calcareous Nannoplankton}

Stratigraphic results of Leg 141 were obtained by the investigation of calcareous nannofossils from about 550 samples. Most of the samples are barren or nannoplankton poor. Age determinations are based on the Standard Nannoplankton Zonation (Martini, 1971; Martini and Müller, 1986).

The nannoplankton assemblages are of low diversity owing to cold-water temperatures, dissolution of the calcareous microfossils, and dilution by the high amount of detrital material. Only a few mainly long-ranging species are present, but not enough to establish a detailed biostratigraphy.

The Pleistocene sequence can be subdivided broadly into upper and lower Pleistocene by using the Zone NN19/NN20 boundary at $0.47 \mathrm{Ma}$. The Pliocene/Pleistocene boundary, normally determined by the extinction of the discoasters, is difficult to recognize because this group, typical of a warm water environment, is absent from the Leg 141 material. The last occurrence of Cyclococcolithus macintyrei, proposed by Bizon and Müller (1977) for the determination of the Pliocene/Pleistocene boundary at $1.6 \mathrm{Ma}$, is also not a useful biostratigraphic event within this region. Cyclococcolithus macintyrei found also in areas dominated by lower surface-water temperatures is generally a good substitute for the discoasters. However, only rare specimens of this species were observed in the studied samples. Because of these difficulties, we decided to use the first occurrence (FO) of the group Gephyrocapsa oceanica (Raffi and Rio, 1979), a Gephyrocapsa with a large central opening.

A subdivision of the upper Pliocene in Leg 141 sediments (nannoplankton Zones NN16-NN18) is impossible. At some sites, small specimens of the genus Reticulofenestra were found. But by using only the light microscope, it is not possible to determine if this form represents a small variety of Reticulofenestra pseudoumbilica, which would give an early Pliocene age (Zone NN15), or if it belongs to part of Zone NN16, because it has been observed from this stratigraphic level in other regions.

It is most likely that the entire recovered sequences belong to the Pleistocene and upper Pliocene; in any case, they are not older than 3.2-3.4 Ma. This is shown by the presence of a very small species of the genus Gephyrocapsa, which has its first appearance at about this 


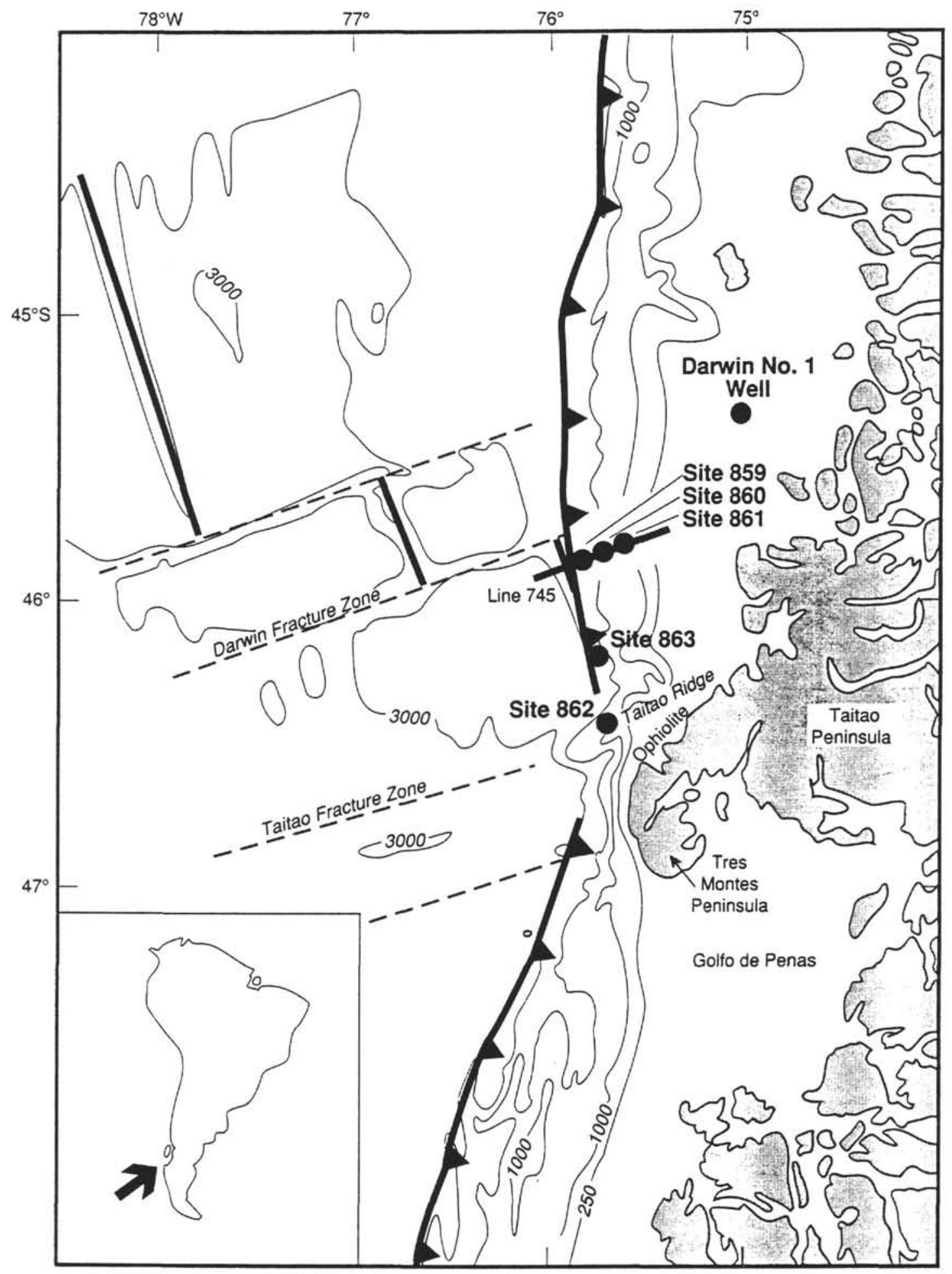

Figure 1. Location map of Sites 859-863.

time. Further on, Pseudoemiliania lacunosa was commonly observed, and this species is unknown from sediments older than Zone NN15.

Nannofossils are apparently more common in the sediments of the lower part of Zone NN16 indicating decreasing water temperature during the late Pliocene. Fluctuations in abundance throughout the Pliocene sequence were observed at Sites 860 and 861 .

Reworked species from older strata (Eocene and lower Miocene) occur rarely throughout the series. Imbrications of the sedimentary sequences certainly exist. However, it was not possible for us to recognize them by biostratigraphic evidence.

\section{Planktonic Foraminifers}

Stratigraphic results and paleotemperature estimations for Leg 141 were obtained by the investigation of planktonic foraminifers from 653 samples. Most of them are poor in planktonic foraminifers, 
and only the uppermost sequences contain richer assemblages. To acquire a sufficient number of specimens, the entire residue was usually picked and to get a comparable value in abundance, the number of foraminifers in $20 \mathrm{~cm}^{3}$ of sediment was calculated.

Temperature is one of the habitat-controlling factors of foraminifer distribution in modern oceans. The taxa of planktonic foraminifers can be divided roughly into warm-water assemblages and coldwater forms. The majority of the Holocene planktonic foraminiferal species lives in tropical and subtropical waters, whereas only a single species, Neogloboquadrina pachyderma (sinistral coiling form), lives in polar waters. The regions where warm-water and cold-water assemblages overlap in distribution, and where the greatest faunal contrast occurs, are designated the Transition Zone (Bé and Tolderlund, 1971). The investigated area falls in the Southern Transition Zone of recent planktonic foraminifers and is bounded and influenced by the Subtropical Zone in the north and by the Subantarctic Zone in the south. Goboconella inflata is the most common taxon in Leg 141 sediments. It appears to be indigenous and therefore a good indicator species of the Transition Zone. However, it is possible to recognize the Truncorotalia truncatulinoides Zone, the Globoconella inflata Zone, and the Globorotalia crassaformis Zone, respectively, the Neogloboquadrina pachyderma (sinistral coiling form) Zone. The FO of Truncorotalia truncatulinoides is strongly influenced by temperature, and, therefore, the base of this zone varies. The zonations used in this paper are summarized in Figure 2. Location, position, water depth, and penetration of each hole are given in Table 1 .

\section{Site 859}

Site 859 is the westernmost site of the east-west profile of Sites 859 through 861 , located most seaward at the deepest water depth.

\section{Calcareous Nannoplankton}

Cores $141-859 \mathrm{~A}-1 \mathrm{H}$ and $-2 \mathrm{H}$ belong to the uppermost Pleistocene (Zone NN21). Nannofossils are few to common (Table 2). The assemblages consist of following species: Helicosphaera carteri, Cyclococcolithus leptoporus, Gephyrocapsa ericsonii, G. oceanica, Syracosphaera pulchra, and Emiliania huxleyi. Reworked taxa from older strata are rare.

The entire underlying sequence is dated late Pliocene (Zones NN16-NN18) and can not be further subdivided. This age is based on the presence of Cyclococcolithus macintyrei, Helicosphaera sellii, a very small Gephyrocapsa sp. and small Reticulofenestra cf. pseudoumbilica. Thus, a significant unconformity of more than 1 Ma exists.

The Pliocene sediments are extremely poor in nannofossils. Most of the samples taken from Hole 859B are barren because of dissolution (Table 3), which may be related to compaction of the sediments and the circulation of fluids within the accretionary wedge. Reworked specimens from older strata (mostly Miocene) were observed in several samples from throughout the entire series.

The biostratigraphic results obtained from Holes 859A and 859B show that the sediments are not older than $3.4 \mathrm{Ma}$, as indicated by the presence of the small Gephyrocapsa sp. and Pseudoemiliania lacunosa. That means that the upper Pliocene has a thickness of almost $470 \mathrm{~m}$. Imbrication within this thick pile of sediments is highly probable, but it is not possible to prove this assumption because of the poor biostratigraphic resolution.

\section{Planktonic Foraminifers}

The biostratigraphic results obtained by the investigation of planktonic foraminifers are based on 44 samples from Hole 859A (down to $145.5 \mathrm{~m}$ below seafloor [mbsf]) and 93 samples $(54.10$ through $80.90 \mathrm{mbsf}$, and 141.20 through $476.10 \mathrm{mbsf}$ ) from Hole $859 \mathrm{~B}$. Foraminifers occurred in Hole $859 \mathrm{~A}$ in $60 \%$ of the observed samples and in $45 \%$ of the samples from Hole $859 \mathrm{~B}$. No foraminifers were obtained from the micrite-cemented stones in Cores 141-859B$18 R,-27 R,-29 R,-37 R$, and -38R. Sample 141-859A-9P-CC from
Table 1. Location, position, water depth, and penetration of Leg 141 holes.

\begin{tabular}{|c|c|c|c|}
\hline Hole & Position & $\begin{array}{l}\text { Water depth } \\
\text { (m) }\end{array}$ & $\begin{array}{l}\text { enetration } \\
\text { (m) }\end{array}$ \\
\hline $859 \mathrm{~A}$ & $45^{\circ} 53.761^{\prime} \mathrm{S}, 75^{\circ} 51.165^{\mathrm{W}}$ & 2741.2 & 146.5 \\
\hline $859 \mathrm{~B}$ & $45^{\circ} 53.720^{\prime}$ S. $75^{\circ} 51.330 \mathrm{~W}$ & 2748.9 & 476.1 \\
\hline $860 \mathrm{~B}$ & $45^{\circ} 51.972$ 's, $75^{\circ} 45.101$ W & 2145.9 & 617.8 \\
\hline $861 \mathrm{~A}$ & $45^{\circ} 51.025^{\prime} \mathrm{S}, 75^{\circ} 41.531 \mathrm{~W}$ & 1667.0 & 9.5 \\
\hline $861 \mathrm{~B}$ & $45^{\circ} 51.025^{\circ} \mathrm{S}, 75^{\circ} 41.531 \mathrm{~W}$ & 1667.0 & 9.5 \\
\hline $861 \mathrm{C}$ & $45^{\circ} 51.025^{\circ} \mathrm{S} .75^{\circ} 41.531 \mathrm{~W}$ & 1652.2 & 353.1 \\
\hline 86ID & $45^{\circ} 51.008^{\prime}$ S. $75^{\circ} 41.499 \mathrm{~W}$ & 1652.2 & 496.3 \\
\hline $862 \mathrm{~A}$ & $46^{\circ} 30475$ 's. $75^{\circ} 49.603 \mathrm{~W}$ & 1274.9 & 22.1 \\
\hline $862 \mathrm{~B}$ & $46^{\circ} 30.475^{\prime}$ S. $75^{\circ} 49.603 \mathrm{~W}$ & 1268.6 & 42.9 \\
\hline $862 \mathrm{C}$ & $46^{\circ} 30.510^{\prime} \mathrm{S}, 75^{\circ} 49.566^{\mathrm{W}}$ & 1228.6 & 102.1 \\
\hline $863 \mathrm{~A}$ & $46^{\circ} 14.210^{\prime}$ S. $75^{\circ} 46.371 \mathrm{~W}$ & 2564.2 & 297.3 \\
\hline $863 \mathrm{~B}$ & $46^{\circ} 14.210^{\circ}$ S, $75^{\circ} 46.371 \mathrm{w}$ & 2564.2 & 742.9 \\
\hline
\end{tabular}

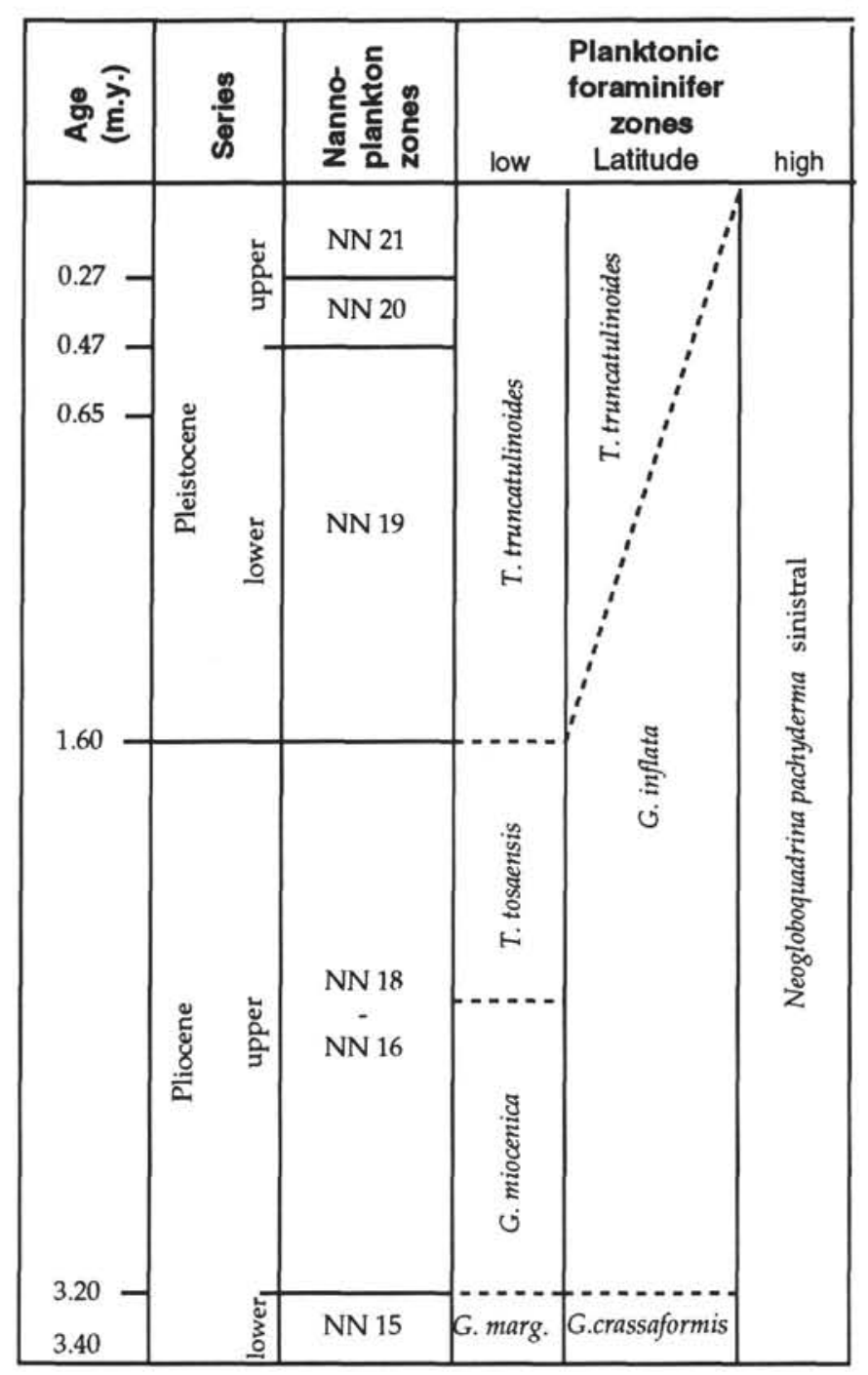

Figure 2. Correlation of nannoplankton and planktonic foraminiferal zones.

58.40 mbsf contains a mixed assemblage of taxa of the Truncorotalia truncatulinoides Zone together with some orange-stained Neogloboquadrina pachyderma (sin.) and is considered to represent in part downhole contamination.

At Site 859 two planktonic foraminiferal events to consider are the FO of T. truncatulinoides in Sample 141-859A-2H-CC and the FO of G. inflata in Sample 141-859B-29R-CC. Unfortunately, both events are followed downhole by assemblages dominated by mainly N. pachyderma (sin.). Consequently, these FO are not thought to 
Table 2. Distribution of calcareous nannoplankton and planktonic foraminifers in Hole 859A.

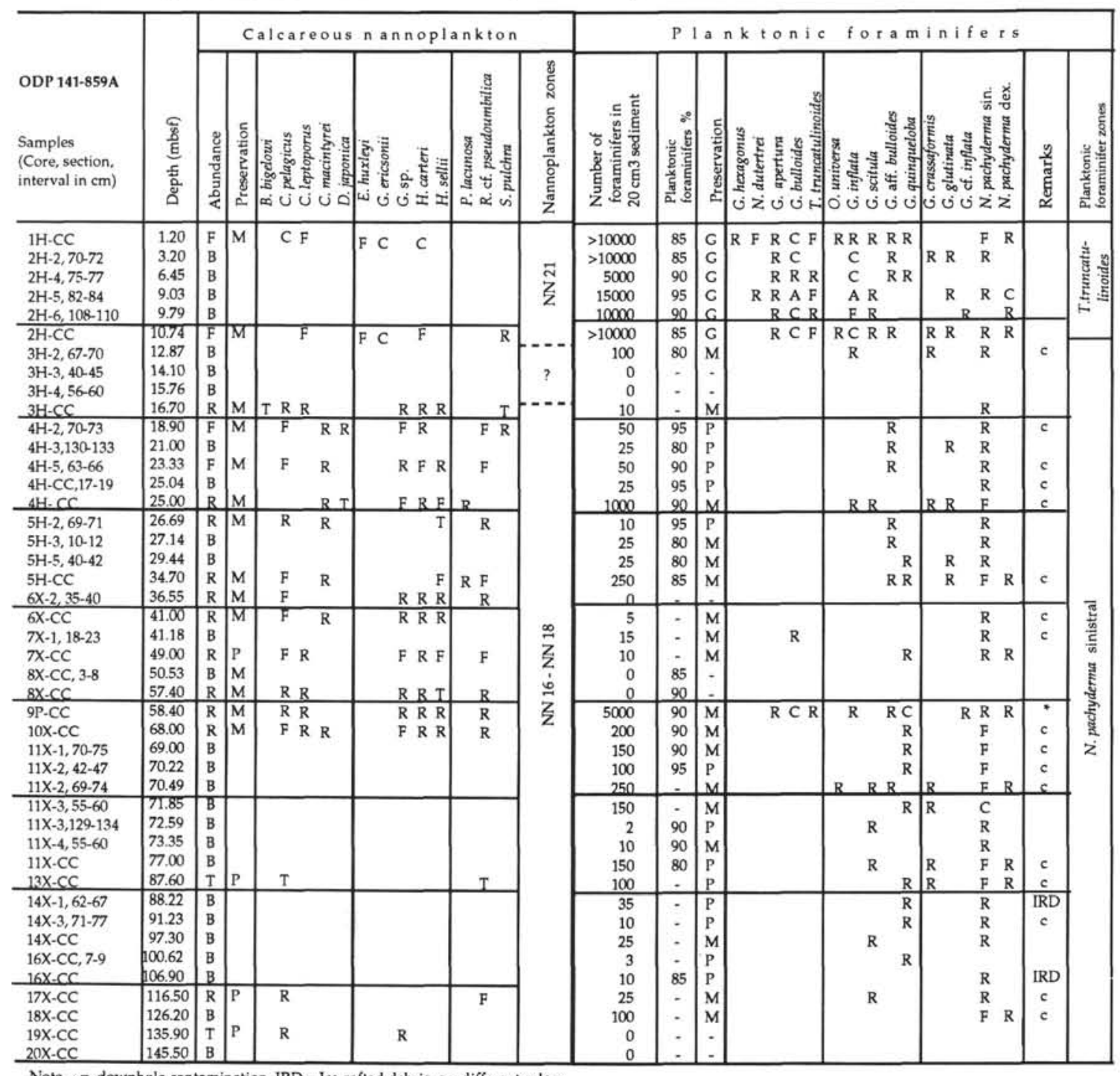

correlate with the general first-appearance datum (FAD) of the taxa, but they are not older than the generally mentioned FAD. According to Srinivasan and Kennett (1981) the FAD of T. truncatulinoides is younger than $2.0 \mathrm{Ma}$ and the FAD of $G$. inflata falls together with the NN15/NN16 nannofossil zone boundary at $3.2 \mathrm{Ma}$. Consequently, Sample 141-859A-2H-CC must be younger than approximately $2 \mathrm{Ma}$, and Sample 141-859B-29R-CC can be dated younger than 3.2 Ma.

In the sequences of Hole $859 \mathrm{~A}$ it is possible to recognize the Pleistocene T. truncatulinoides Zone from the top down to 10.74 mbsf (Cores 141-859A-1H through -2H-CC). Planktonic foraminifers are abundant and well preserved, mainly in the uppermost 1.20 $\mathrm{m}$. The assemblages consist of 15 species including tropical/subtropical taxa such as Globorotaloides hexagonus and Neogloboquadrina dutertrei. The calculated number of foraminifers in $20 \mathrm{~cm}^{3}$ sediment is usually more than 10,000 specimens. Below $10.74 \mathrm{mbsf}$ the whole sequence in Hole 859A and also in Hole $859 \mathrm{~B}$ is extremely poor or barren in planktonic foraminifers (no more than 1000 specimens in $20 \mathrm{~cm}^{3}$ sediment) and of low diversified assemblages with less than six taxa. $N$. pachyderma in its sinistral coiling mode characterizes the entire sequence, therefore, and because of the inconsistent appearance of other taxa the sequence down to the base of Hole $859 \mathrm{~B}$ at $476.10 \mathrm{mbsf}$ is placed in the Neogloboquadrina pachyderma Zone. The assemblages commonly contain colored foraminifers. The in-situ specimens are gray-white. The yellow-red displaced specimens are mostly small specimens of $N$. pachyderma (sin.). In Sample 141$859 \mathrm{~A}-5 \mathrm{H}-5,40-42 \mathrm{~cm}$, at 29.44 mbsf Bolboforma reticulata indicates reworked sediments of middle Miocene age. Downhole from Sample 141-859B-22R-CC (321.90 mbsf), the foraminifers are decalcified and deformed, indicating fluids and stress in the wedge. Below Sample 141-859B-32R-CC at 418.30 mbsf, fewer than five foraminifers in $20 \mathrm{~cm}^{3}$ sediment were found.

\section{Site 860}

\section{Calcareous Nannoplankton}

Core 141-860B-1H through Sample -2H-3, $60 \mathrm{~cm}$, belongs to the upper Pleistocene (Zone NN21) with following assemblage (Table 4): Coccolithus pelagicus, Helicosphaera carteri, Cyclococcolithus leptoporus, Emiliania huxleyi, Gephyrocapsa ericsonii, and G. oceanica. Nannofossils are common. No age determination is possible for Sections $141-860 \mathrm{~B}-2 \mathrm{H}$ through $-2 \mathrm{H}-\mathrm{CC}$ owing to the absence of nannofossils.

Zone NN20 was determined in Core 141-860B-3H by the presence of Gephyrocapsa caribbeanica, but nannofossils are rare in the core. 
Core 141-860B-4H through Section 141-860B-17X-2 belong to the lower Pleistocene (Zone NN19), as shown by the presence of Gephyrocapsa oceanica, G. caribbeanica, and Pseudoemiliania lacunosa. Nannofossils are common only in Cores 141-860B-7H and $-16 \mathrm{X}$. All other samples of the lower Pleistocene sequences are poor in nannoplankton. These results show that the Pliocene/Pleistocene boundary lies about $60 \mathrm{~m}$ deeper than given in Behrmann, Lewis, Musgrave, et al. (1992).

Beside changes in the abundance of nannofossils, the assemblages are the same from Section 141-860B-17X-3 down to Core 141-860B$70 \mathrm{X}$. This sequence is placed in the upper Pliocene (Zones NN16NN18). It was not possible to confirm repetitions within the Pliocene sequence as evidenced by the study of planktonic foraminifers. However, repeated changes in abundance of nannofossils throughout the sequences may indicate imbrications and repetitions. Cores 141-860B$17 \mathrm{X},-21 \mathrm{X}$, to Section $-22 \mathrm{X}-2,-31 \mathrm{X},-32 \mathrm{X}$, and $-58 \mathrm{X}$ are rich in nannoplankton with following species: Coccolithus pelagicus, Cyclococcolithus leptoporus, C. macintyrei, Gephyrocapsa sp., Pseudoemiliania lacunosa, Helicosphaera carteri, H. sellii, Discolithina japonica, Pontosphaera pacifica, and the small variety of Reticulofenestra cf. pseudoumbilica. The more common occurrence of Discolithina japonica and Pontosphaera pacifica has been observed within the upper Pliocene in other regions (Müller, 1979).

The lowermost part of the sequence (Cores 141-860B-62X to $-70 \mathrm{X}$ ) might belong to the lower Pliocene, owing to the presence of small Reticulofenestra cf. pseudoumbilica. But this is not a clear evidence for this age assignment.

Large parts of the Pliocene sequence are almost barren (Cores 141-860B-24X to $-29 \mathrm{X}$, and 141-860B-33X to $-70 \mathrm{X}$ ); only a few samples yielded rare nannofossils. However, the entire sequence is not older than $3.4 \mathrm{Ma}$ as indicated by the presence of Pseudoemiliania lacunosa and the small Gephyrocapsa sp. down to at least Core 141-860B-61X.

\section{Planktonic Foraminifers}

The biostratigraphy based on planktonic foraminifers from Site 860 is based on 157 samples from Hole $860 \mathrm{~B}$ from the top down to 617.82 mbsf. Planktonic foraminifers occur in $85 \%$ of the investigated samples.

At Site 860 the FO of T. truncatulinoides was observed in Sample $141-860 \mathrm{~B}-16 \mathrm{X}-3,32-38 \mathrm{~cm}$. Therefore, the sequence down to $120.12 \mathrm{mbsf}$ belongs to the $T$. truncatulinoides Zone. The uppermost $6.50 \mathrm{~m}$ of this sequence contain rich assemblages with $T$. truncatulinoides, Globorotaloides hexagonus, Neogloboquadrina dutertrei. Orbulina universa, Globigerina apertura, and $G$. bulloides. The presence of these species and $G$. inflata indicates that tropical/subtropical taxa occurred together in transitional water masses and that warm temperatures had influenced the assemblages in the latest Pleistocene. The downhole occurrences of $N$. pachyderma indicate that more subpolar temperatures influenced the assemblages of planktonic foraminifers. The index fossil $T$. truncatulinoides occurs below $6.50 \mathrm{mbsf}$ only sporadically in two samples (Samples 141-860-12X$2,35-39 \mathrm{~cm}$, and $-16 \mathrm{X}-3,32-38 \mathrm{~cm})$. Therefore, the placement of the lower boundary of the $T$. truncatulinoides Zone is very uncertain. Nevertheless, in Hole 860B it corresponds well with the Zone NN19/ $\mathrm{NN} 18$ boundary determined by calcareous nannofossils. The FO of $T$. truncatulinoides lies in a sequence common in $G$. inflata, which indicates transitional water masses.

The sediments below 24.70 mbsf contain translucent white and yellow-orange foraminifers together, indicating debris flows or other downslope sedimentation. No differences exist in the diversity of the white and the colored shells, which also show no difference in age. The calculated number of foraminifers in the samples of the T. truncatulinoides Zone fluctuated cyclically between zero and more than 25,000 specimens in $20 \mathrm{~cm}^{3}$ of sediment. The uppermost cycle extends to $9.50 \mathrm{mbsf}$. The underlying cycle to $49 \mathrm{mbsf}$ has its highest abundances of foraminifers between 20 and $33 \mathrm{mbsf}$. The next cycle is to $91.90 \mathrm{mbsf}$, and until $116.80 \mathrm{mbsf}$ most of the samples are barren in foraminifers, except that samples between 107.20 and $110.80 \mathrm{mbsf}$ contain small amounts of stained, and therefore displaced, foraminifers. These fluctuations in the abundance of foraminifers may reflect different water paleotemperatures, but temperature assignments are difficult and tentative.

Below $120.12 \mathrm{mbsf}$ the sequence can generally be described as an alternation of assemblages with and without $G$. inflata. This fact may indicate imbrication and repetitions. $G$. inflata was not observed between 155.50 through $192.02 \mathrm{mbsf}, 203.70$ and $242.50 \mathrm{mbsf}$, and 272.78 and 300.10 mbsf. Below $328.70 \mathrm{mbsf}, G$. inflata occurs sporadically at $376.90,425.30,451.20$ and 532.49 through 535.04 mbsf, where the deepest observation of $G$. inflata was fixed. The FAD of $G$. inflata usually marks the boundary between early and late Pliocene, which is the boundary between the Globorotalia crassaformis Zone and the $G$. inflata Zone, respectively (Kennett and Srinivasan, 1983; Srinivasan and Kennett, 1981). The LO of Globorotalia cf. sphericomiozea may indicate the lower Pliocene in Sample 141-860B-65X$\mathrm{CC}$ and below (Table 4).

\section{Site 861}

Site 861 is the easternmost site of the west-east transect of Leg 141 approximately parallel along to the $45^{\circ} \mathrm{S}$ latitude. This site is located the farthest landward and at the shallowest water depth. Sediments recovered in Holes 861A through Hole 861D from the seafloor to $496.30 \mathrm{mbsf}$ represent a stratigraphic sequence ranging from Quaternary to Pliocene.

\section{Calcareous Nannoplankton}

The sediments of Core $1 \mathrm{H}$ from Holes $861 \mathrm{~A}$ and $861 \mathrm{~B}$ are rich in nannofossils typical of the late Pleistocene Emiliania huxleyi Zone (NN21; Tables 5 and 6). The more diversified assemblages indicate the influence of warmer surface-water masses.

Nannofossils are few within the Pleistocene of Hole 861C, and they become rare throughout the Pliocene with exception of the lower part of Zone NN16 (Table 7). Their scarcity is the result of dissolution and dilution by a large amount of detrital material. The assemblages are of low species diversity, and the species are smaller than normal, owing probably to low surface-water temperatures. However, this may also partially reflect a relative enrichment related to selective dissolution that destroys the larger specimens first. The low diversity of the assemblages precludes conclusions about paleoclimatic changes.

Cores $141-861 \mathrm{C}-1 \mathrm{H}$ through $-4 \mathrm{H}$ belong to nannoplankton Zone $\mathrm{NN} 21$ as shown by the presence of Emiliania huxleyi. Nannofossils are few to common, and they show signs of dissolution in Core 141-861C$1 \mathrm{H}$. The assemblages consist of the following species: Helicosphaera carteri, Coccolithus pelagicus, Gephyrocapsa ericsonii, G. oceanica, Cyclococcolithus leptoporus, and Emiliana huxleyi. Other species such as Syracosphaera pulchra, S. mediterranea, Rhabdosphaera claviger, Braarudosphaera bigelowi, Pontosphaera syracusana, and Scapholithus fossilis were observed only sporadically.

The sediments belonging to nannoplankton Zone NN20 contain only rare nannofossils. The assemblages are very poor, containing only Helicosphaera carteri, Cyclococcolithus leptoporus, Coccolithus pelagicus, and Gephyrocapsa ericsonii. Core 141-861C-7H to Section 141-861C-15X-4 is almost barren of nannoplankton. Nannofossils become more common within the lowermost part of Core 141$861 \mathrm{C}-15 \mathrm{X}$. The boundary between nannoplankton Zones NN19 and NN20 lies probably at the base of Core $141-861 \mathrm{C}-15 \mathrm{X}$, where the last occurrence of Pseudoemiliania lacunosa was observed. Nannofossils are more frequent within the sediments attributed to Zone NN19.

The upper part of the Pliocene section is very poor in nannoplankton. Apart from core-catcher Sample 141-861C-24X, the sediments from Cores 141-861C-21X through $-30 \mathrm{X}$ are barren. Nannofossils 
Table 3. Distribution of calcareous nannoplankton and planktonic foraminifers in Hole 859B.

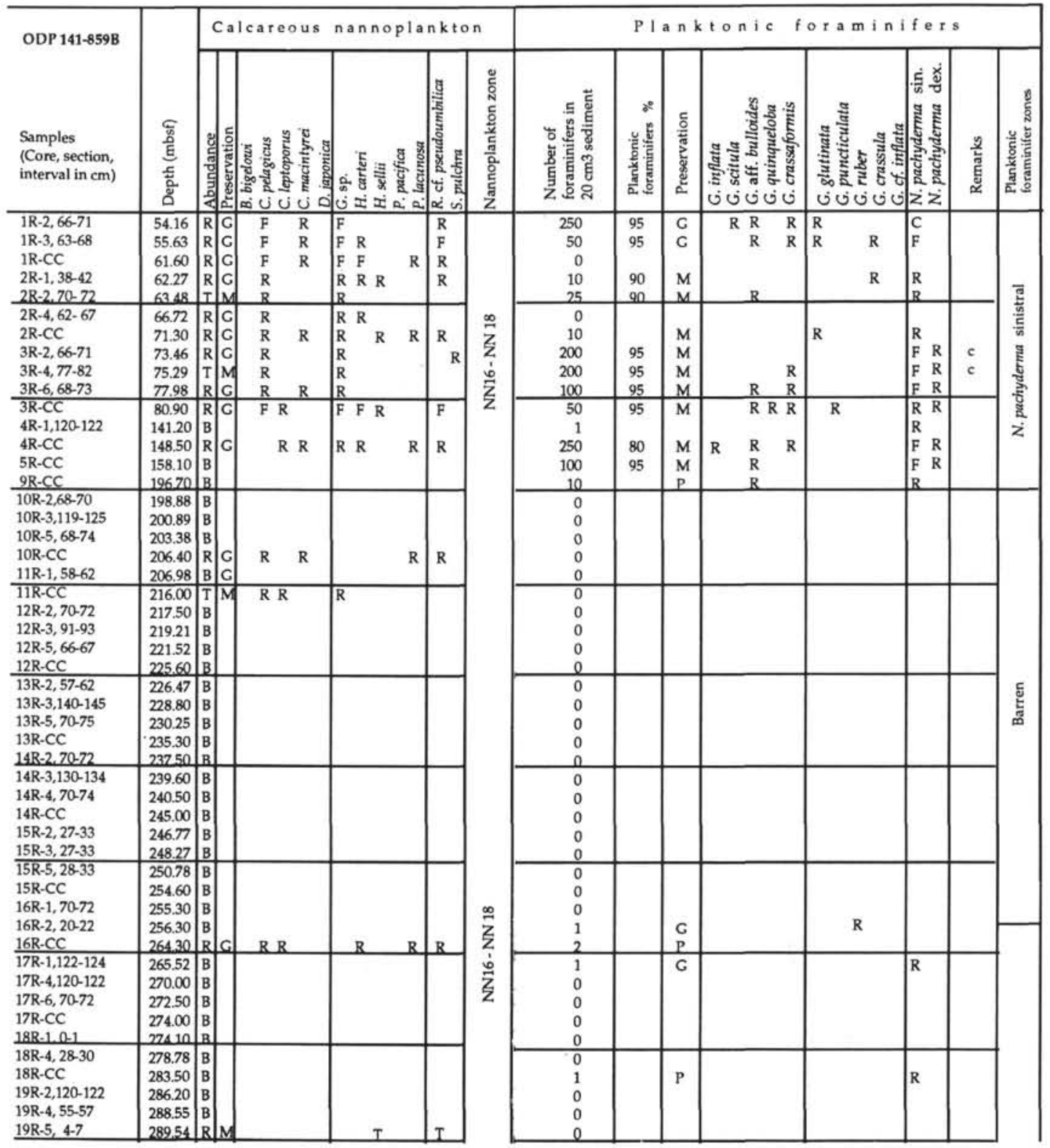

become more common in Core 141-861C-34X, but decrease again in Core 141-861C-35X through -37X. The assemblages are of very low diversity containing Cyclococcolithus macintyrei, Helicosphaera carteri, H. sellii, Pseudoemiliania lacunosa, and Gephyrocapsa sp. The Pliocene/Pleistocene boundary is determined tentatively between Cores 141-861C-20X and -21X by the FO of Gephyrocapsa oceanica. Cores 141-21X through -25X were barren of calcareous nannoplankton. Small specimens of Reticulofenestra cf. pseudoumbilica are present from Core 141-861C-34X. This lowermost part of the sequence most probably belongs to the lower part of Zone NN16 (2.6-3.2 Ma.). This age agrees with the results obtained by foraminifers.

Hole 861D was washed down to $342.30 \mathrm{mbsf}$. The entire sequence is assigned to the upper Pliocene (Zones NN16-NN18; Table 8). Further subdivision is impossible because of the scarcity of nannofossils.

Core 141-861D-1R belongs to the upper Pliocene (Zone NN16NN18) with the following assemblage: Coccolithus pelagicus, Gephyrocapsa sp., Cyclococcolithus macintyrei, C. leptoporus, Pseudoemiliania lacunosa, Discolithina japonica, Helicosphaera carteri, and $H$. sellii. Sample 141-861D-2R-2, 83-88 cm, is rich in strongly overgrown nannoplankton, which may be due to the circulation of fluids. The same nannofossil species found in the core-catcher sample of Core 141-861D-2R are well preserved without any sign of overgrowth. There was no recovery from Cores 141-861D-3R through $-5 R$. Core 141-861D-6R contains only a few nannofossils whereas they are common in Cores 141-861D-7R through -9R. The nannoplankton assemblages of this part in Hole 861D correspond with those observed within the lower part in Hole $861 \mathrm{C}$ in containing the small variety of Reticulofenestra cf. pseudoumbilica. In addition, the presence of extremely rare discoasters in Cores 141-861D-7R and -12R may indicate warmer surface-water temperatures, as was also the case for Core 141-861D$16 \mathrm{R}$. Very rare reworked specimens from Eocene and Miocene sediments occur in several samples.

Based on foraminifers Cores 141-861D-8R through -16R belong to the lower Pliocene $G$. crassaformis Zone corresponding to nannoplankton Zone NN15. However, there is no real evidence for this zone from the nannofossil occurrences. 
Table 3 (continued).

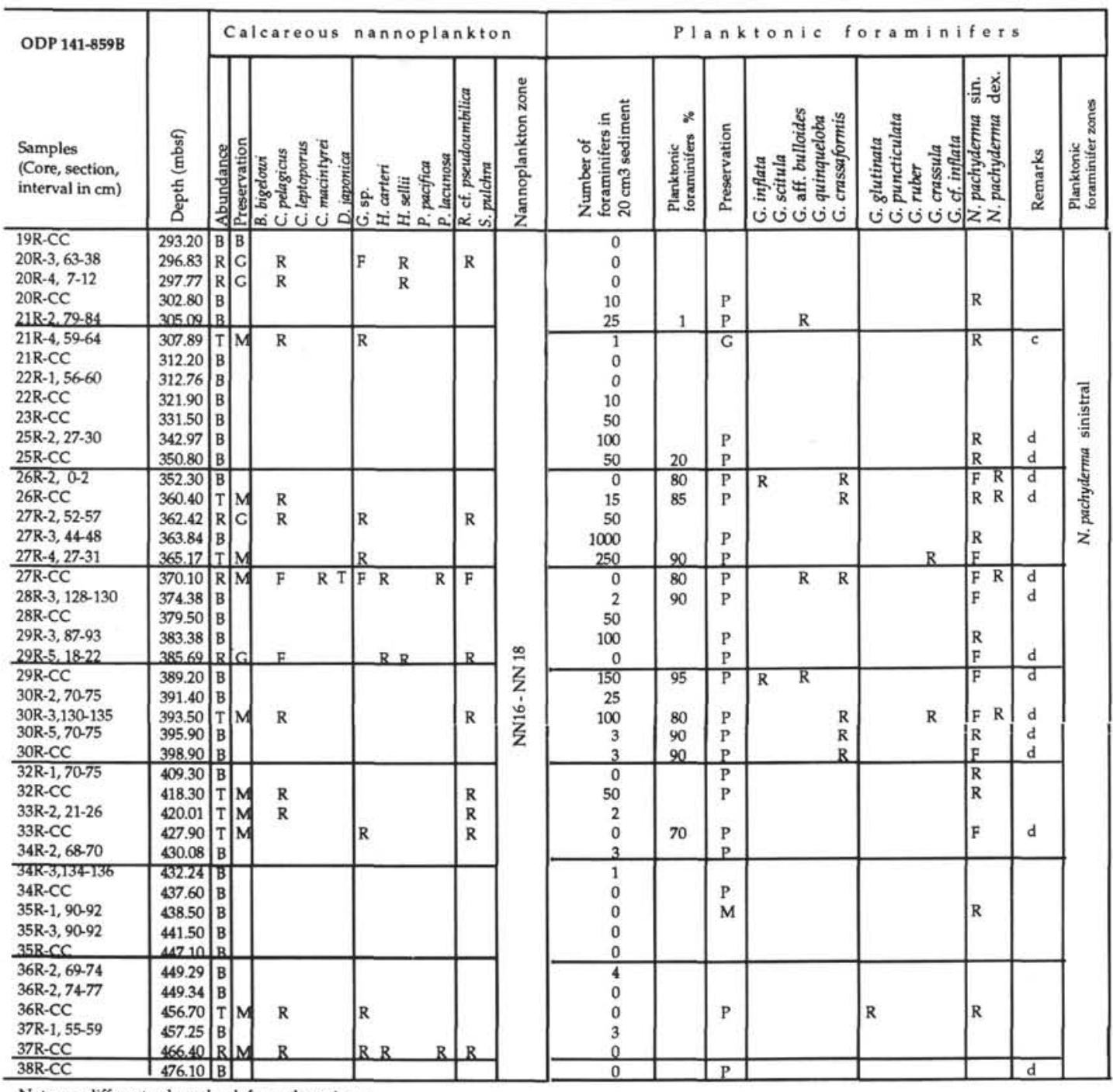

\section{Planktonic Foraminifers}

The biostratigraphic results obtained from planktonic foraminifers are based on investigation of nine samples from Hole 861 A and six samples from Hole $861 \mathrm{~B}$, which penetrates only the upper $10 \mathrm{~m}$ of the sequence, as well as on studies of 131 samples from Hole 861C (353.10 m total depth) and 35 samples from Hole 861D (344.48 to $496.30 \mathrm{mbsf}$ ).

At Site 861 two recognized planktonic foraminifer events are the FO of T. truncatulinoides, which defines the lower boundary of the $T$. truncatulinoides Zone in Sample 141-861C-16X-4, 30-35 cm, at $133.70 \mathrm{mbsf}$, and the FO of $G$. inflata, which marks the lower boundary of the $G$. inflata Zone in Sample 141-861D-8R-1, 46-51 cm, at $410.26 \mathrm{mbsf}$. On the basis of planktonic foraminifers three zones are distinguishable in the Quaternary and Pliocene series: the T. truncatulinoides Zone, the $G$. inflata Zone, and the $G$. crassaformis Zone.

Paleotemperatures are apparently reflected by the foraminiferal assemblages. The uppermost $3 \mathrm{~m}$ of the T. truncatulinoides Zone contain well-preserved and rich assemblages with Globorotaloides hexagonus, Beella digitata, Neogloboquadrina dutertrei, Globigerina apertura, $G$. bulloides, Orbulina universa, and T. truncatulinoides accompanied by $G$. inflata. This indicates the occurrence of tropical/subtropical taxa during the late Pleistocene in transitional water masses. Down to 69.50 mbsf most of the samples contain $T$. truncatulinoides and $N$. pachyderma, which indicate lower temperatures. The FO of $T$. truncatulinoides is documented only by one whole and a broken specimen, which shows the uncertainty of the zonal boundary. Cyclic fluctuations in abundances of foraminifers as observed in the T. truncatulinoides Zone of Hole 860B were also recognized within the sequences from Site 861 . Low number of foraminifers (Tables 5, 6, and 7) coincides roughly with even isotope stages, corresponding to cool intervals (e.g. at $7.15 \mathrm{mbsf}=$ oxygen isotope event 2.2 according Schönfeld and Spiegler (this volume), between 12 and $14 \mathrm{mbsf}=$ event 4.2 , at $27.59 \mathrm{mbsf}=$ event 6.2 , and around $48 \mathrm{mbsf}=$ oxygen isotope event 8 ). Below $42.80 \mathrm{mbsf}$ most of the samples contain yellow- to red-colored foraminifers together with white specimens, which documents downslope redeposition also described from Site 860 .

\section{Site 862}

Site 862 was drilled to determine the basement lithology of the Taitao Ridge which was reached in Hole $862 \mathrm{C}$. 
Table 4. Distribution of calcareous nannoplankton and planktonic foraminifers in Hole 860B.

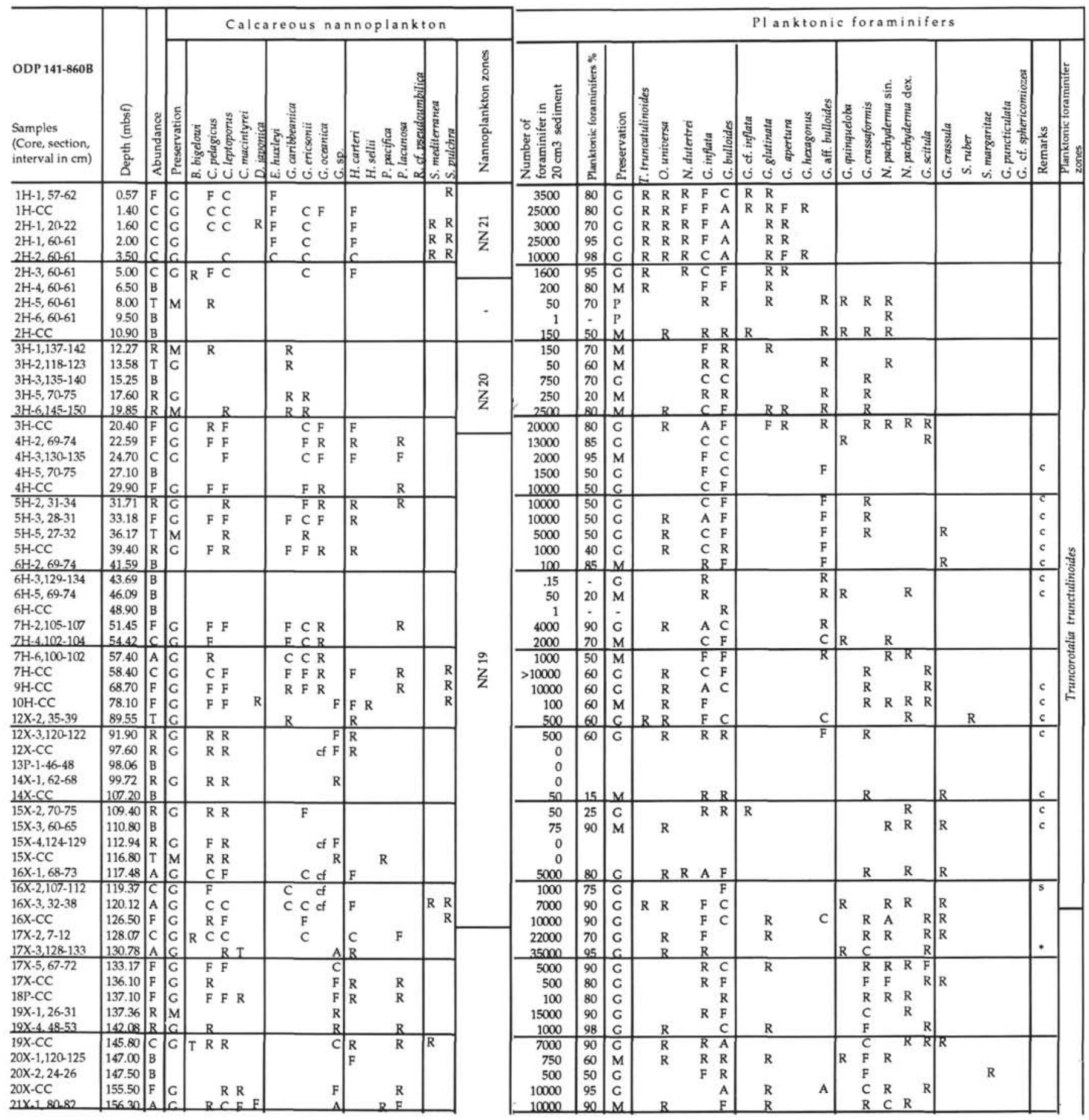

\section{Calcareous Nannoplankton}

Cores $141-862 \mathrm{~A}-1 \mathrm{H}$ and $-2 \mathrm{H}$ are almost barren of autochthonous nannofossils (Table 9). However, reworked taxa from Paleogene and Miocene sediments are present in several samples. Only Core-catcher Sample 141-862A-3H contains a few nannoplankton. The following species were observed: Coccolithus pelagicus, Cyclococcolithus leptoporus, C. macintyrei, Pseudoemiliania lacunosa, and Gephyrocapsa sp., which indicates a late Pliocene age (Zones NN16-NN18).

\section{Planktonic Foraminifers}

Planktonic foraminifers are well preserved and abundant in the uppermost $25 \mathrm{~cm}$ of soft green clay. Globorotaloides hexagonus, Beella digitata, Neogloboquadrina dutertrei, Orbulina universa, Globigerina apertura, G. bulloides together with Truncorotalia truncorotaloides, and Globoconella inflata indicate a subtropical influence during the $T$. truncorotaloides Zone of latest Pleistocene, as mentioned also for Sites 859, 860, and 861. The FO of T. truncorota- 
Table 4 (continued).

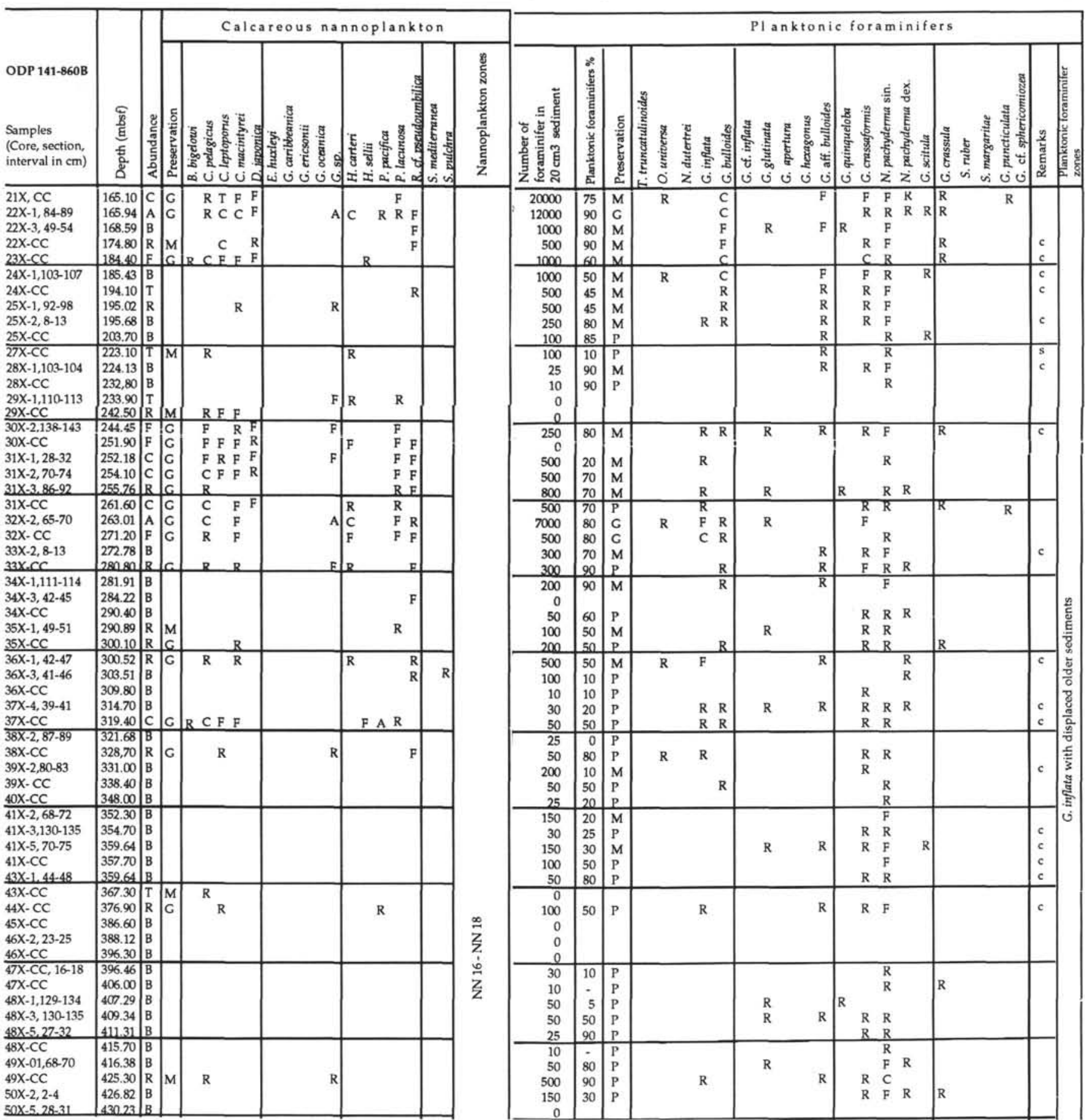

loides in Sample 141-862A-1H-1, 101-104 cm (1.01 mbsf) indicates the base of the $T$. truncorotaloides Zone and the FO of $G$. inflata is to observe in Sample 141-862A-1H-CC (5.40 mbsf). Below $1.01 \mathrm{mbsf}$ stained foraminifers document reworking as observed in the other Pleistocene/Pliocene sequences off Chile. Downhole, N. pachyderma ( $\sin$.) dominates the assemblages, indicative of a cold-water environment. Sample 141-862C-6R-1 from Piece 6 is a layer of indurated sandstones intercalated between basaltic rocks above and below. The marine origin of the coarse sandstone is documented by sea urchin- spines and traces of miliolid foraminifers. In addition, Forsythe et al. (this volume) decribed from a fine-grained portion of this sandstone foraminifers late Paleocene in age.

\section{Site 863}

Site 863 was drilled at the base of the trench slope at the point where the ridge is being subducted. 
Table 4 (continued).

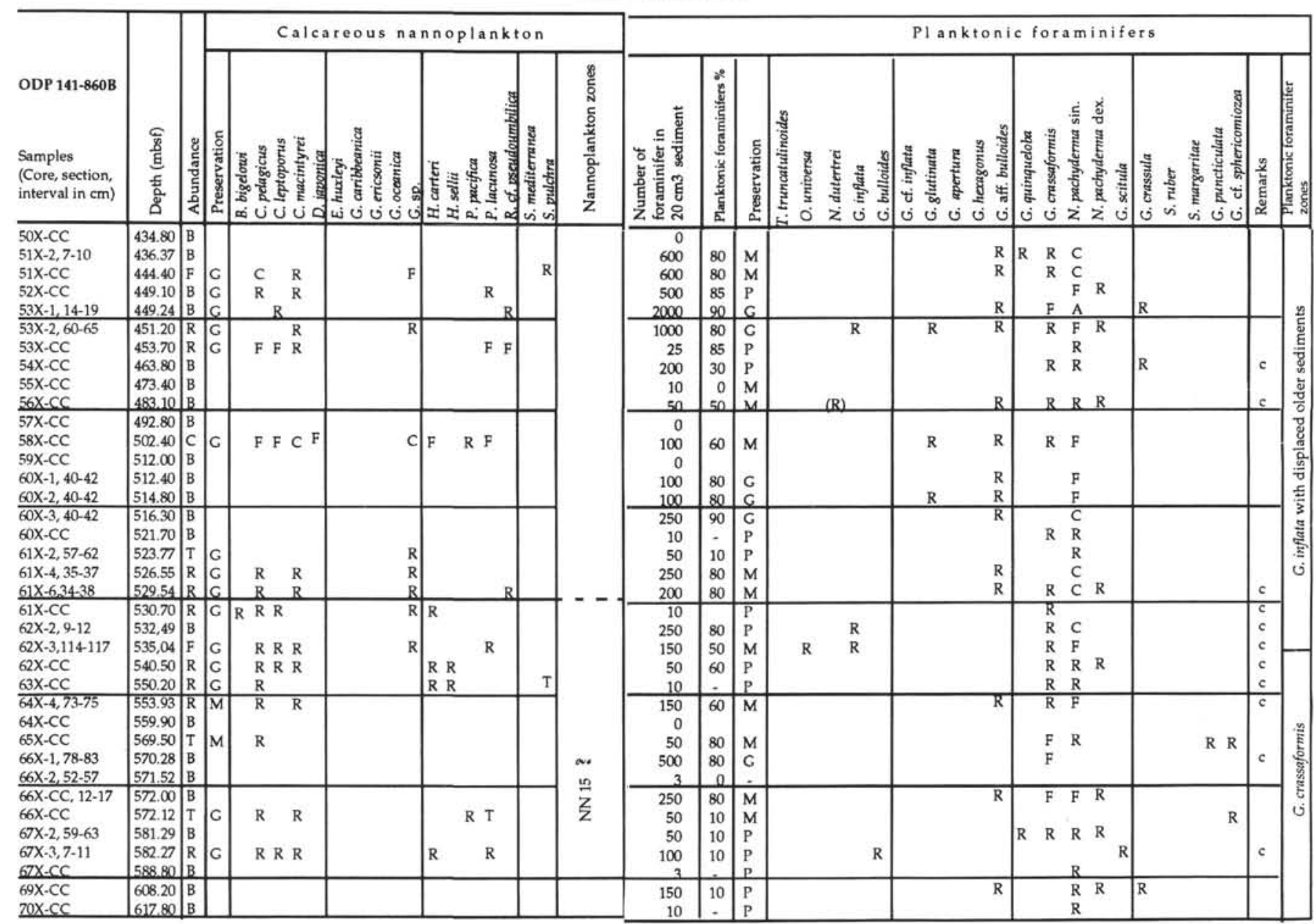

Note: $\boldsymbol{*}=$ downhole contamination, $\mathrm{c}=$ different colors.

Table 5. Distribution of calcareous nannoplankton and planktonic foraminifers in Hole 861A.

\begin{tabular}{|c|c|c|c|c|c|c|c|c|c|c|c|}
\hline \multirow[b]{2}{*}{$\begin{array}{l}\text { ODP 141-861A } \\
\text { Samples } \\
\text { (Core, section, } \\
\text { interval in cm) }\end{array}$} & \multirow[b]{2}{*}{ 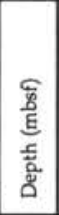 } & \multicolumn{4}{|c|}{ Calcareous nannoplankton } & \multicolumn{6}{|c|}{ Planktonic foraminifers } \\
\hline & & 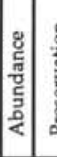 & 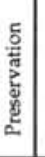 & 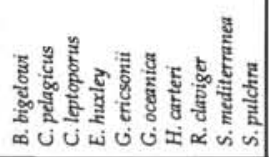 & 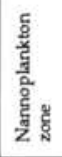 & 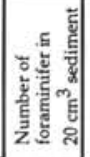 & 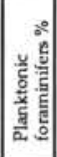 & 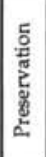 & 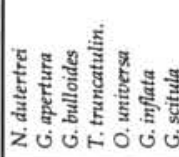 & 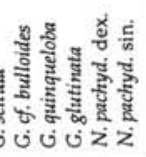 & 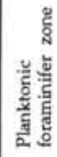 \\
\hline $1 \mathrm{H}-1,8-13$ & 0.08 & A & c & FRFFF RRRRR & & 40000 & 95 & G & A F F A R & & \\
\hline & 1.30 & $\mathrm{R}$ & G & R R R F R & & 4500 & 90 & $\mathrm{G}$ & $\mathrm{RAR} A$ & & \\
\hline & 1.78 & C $N$ & M & FFFAR F & & 2500 & 90 & $\mathrm{M}$ & A R & $R^{R} R$ & ปี \\
\hline $3,9-13$ & 3.09 & c) & $\mathrm{G}$ & CFF F & $\overline{\mathrm{s}}$ & 2500 & 80 & $\mathrm{G}$ & F R & $R R \quad R$ & हू \\
\hline - $-4,109-114$ & 5.59 & & & & $z$ & 5000 & 80 & $\mathrm{G}$ & $C R$ & & $\Xi$ \\
\hline $1 \mathrm{H}-5,118-123$ & 7.18 & \begin{tabular}{l|l|l|l|l|}
$R$ & $C$ \\
\end{tabular} & $\bar{G}$ & & & 1500 & 70 & $\mathrm{G}$ & F R & & छ \\
\hline & 8.37 & $\mathrm{~T} \mathrm{M}$ & M & & & 180 & 50 & $\mathrm{M}$ & $\mathrm{R} R$ & $R \mathbb{R} R$ & है \\
\hline $1 \mathrm{H}-7,20-25$ & 9.20 & $\mathrm{~F}$ C $\mathrm{C}$ & G & F R R R & & 1500 & 70 & $\mathrm{G}$ & C R & $\mathrm{R} R$ & $\underline{E}$ \\
\hline $1 \mathrm{H}-\mathrm{CC}$ & 9.50 & $\mathrm{~F}$ M & M & $F R \subset C R R$ & & 1500 & 75 & $\mathrm{G}$ & $\mathrm{F} \mathrm{R} \quad \mathrm{C}$ & $\mathrm{R}$ & \\
\hline
\end{tabular}

\section{Calcareous Nannoplankton}

The biostratigraphic results obtained by the investigation of calcareous nannofossils are based on 77 samples from Hole $863 \mathrm{~A}$ and 76 samples from $863 \mathrm{~B}$.

The upper part of the sequence encountered in Hole $863 \mathrm{~A}$ is poor in nannofossils (Cores 141-863A-1H through -23X). Only Sample 141-863A-8H-CC contains common nannoplankton with the following species: Cyclococcolithus leptoporus, Coccolithus pelagicus,
Gephyrocapsa ericsonii, G. oceanica, and Helicosphaera carteri, which are typical for the upper Pleistocene, and probably indicate Zone NN20. Reworked species from the Miocene were observed in several samples. Nannofossils are common from Cores 141-863A$24 \mathrm{X}$ through $-28 \mathrm{X}$, and the assemblage gives an early Pleistocene age (Zone NN19) with Gephyrocapsa oceanica, G. ericsonii, Pseudoemiliania lacunosa, Helicosphaera carteri, Coccolithus pelagicus, and Cyclococcolithus leptoporus. The same assemblage was found in Sample 141-863A-31-CC (Table 10). 
Table 6. Distribution of calcareous nannoplankton and planktonic foraminifers in Hole 861B.

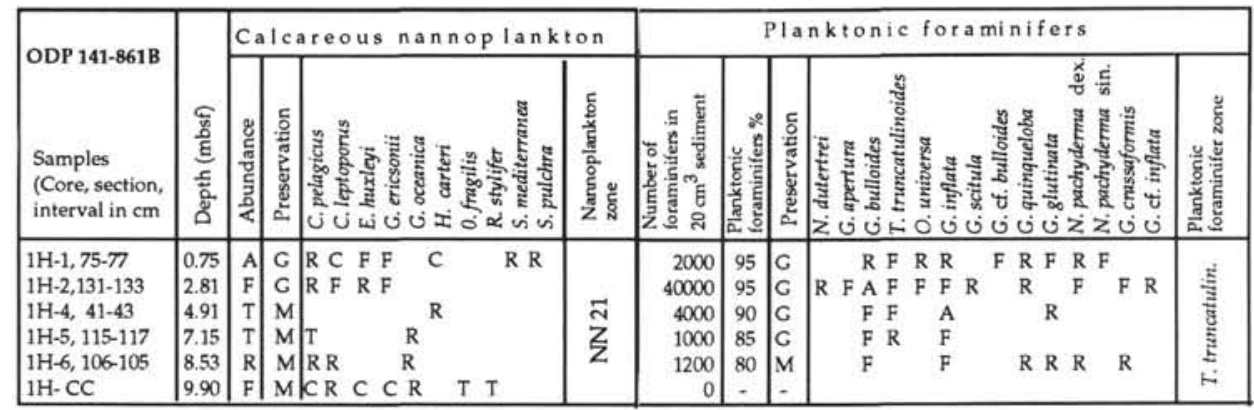

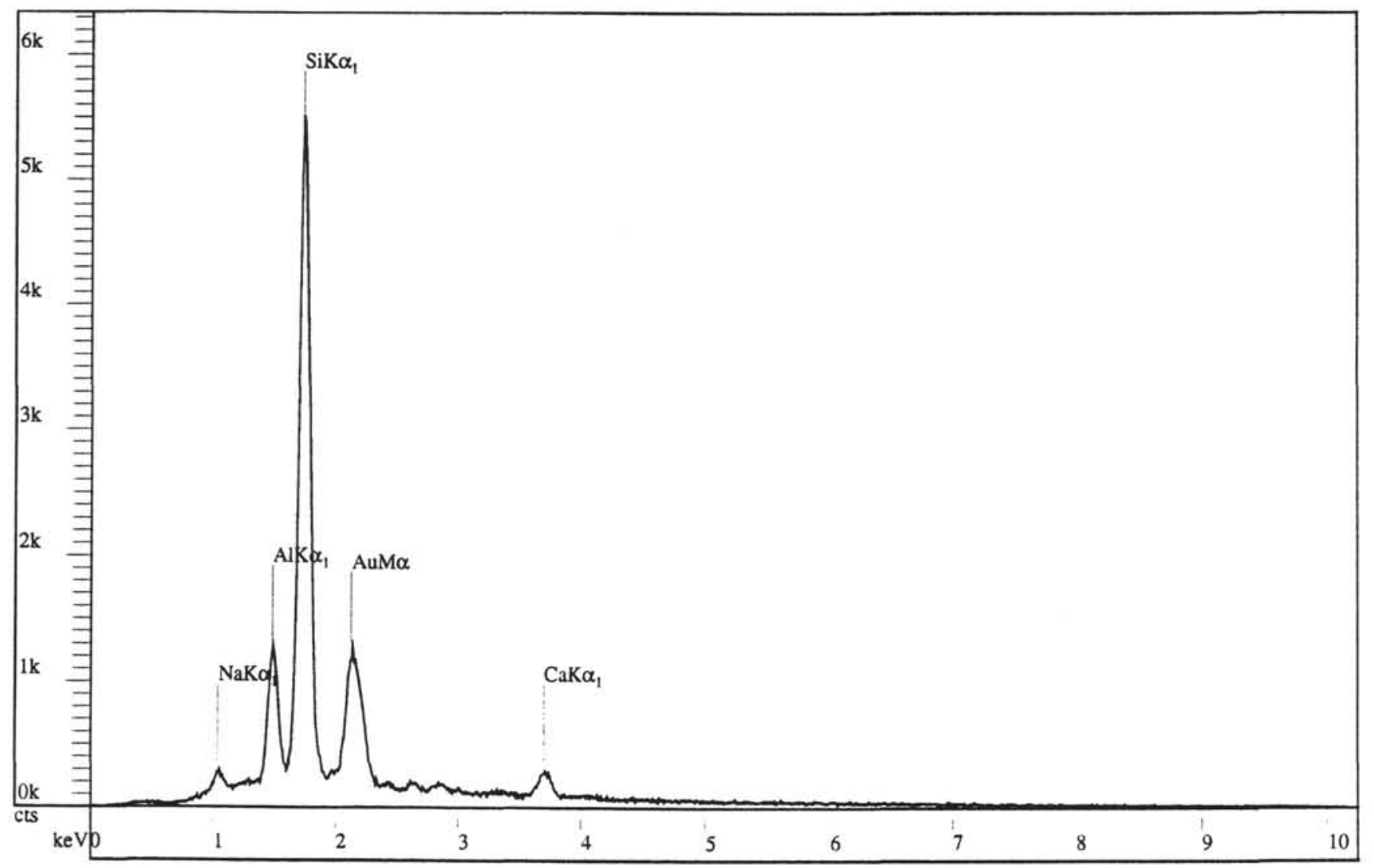

Figure 3. EDAX analysis of a silicified Gibicidoides sp. from Sample 141-863B-30X-CC (569.10 mbsf).

Hole $863 \mathrm{~B}$ was drilled about $10 \mathrm{~m}$ to the east of Hole $863 \mathrm{~A}$. Nannofossils are abundant but they are of small size. The assemblages observed from the top to the base of the sequence are the same, and are dominated by Gephyrocapsa ericsonii and G. caribbeanica. Species such as Gephyrocapsa oceanica, Helicosphaera carteri, $C y$ clococcolithus leptoporus, and Coccolithus pelagicus are less frequent. The entire sequence is placed in the Zone NN20 of upper Pleistocene (Table 11).

\section{Planktonic Foraminifers}

The results are based on the investigation of 78 samples taken from Hole $863 \mathrm{~A}$ and 73 samples from Hole $863 \mathrm{~B}$. The analysis of planktonic foraminifers placed the sequence in the $G$. inflata Zone. In Sample 141-863A-1H-1, 18-20 cm (0.18 mbsf) orange-stained foraminifers indicate displacement. T. truncatulinoides are observed be- tween 15.30 and 23.74 mbsf and again between 68.53 and 75.45 mbsf. Sample 141-863A-3H-4, 114-119 cm (23.74 mbsf), contains a very rich assemblage with subtropical indicators like $N$. dutertrei, $G$. aequilateralis, G. hexagonus, and some large specimens of $O$. universa, which have been normally observed within the uppermost meters of the recovered sequences off the southern Chilean coast. These sediment intercalations are characterized by typical assemblages of the upper T. truncatulinoides Zone and could be interpreted as tectonic imbrication of the sequence. The tectonical influence is also documented by strongly deformed foraminifers below $435 \mathrm{mbsf}$. Below 355 mbsf silica partly replaces the carbonate of the tests. Inner parts of the foraminifers show often residues of calcite. In samples containing high amounts of diagenetic carbonate only silicified and broken specimens were found. An EDAX analysis of a silicified benthic foraminifer Cibicidoides sp. shows the high amount of silica and some signals for clayey minerals (Fig. 3). This may indicate the influence of fluids circulating within the accretionary wedge. 
Table 7. Distribution of calcareous nannoplankton and planktonic foraminifers in Hole 861C.

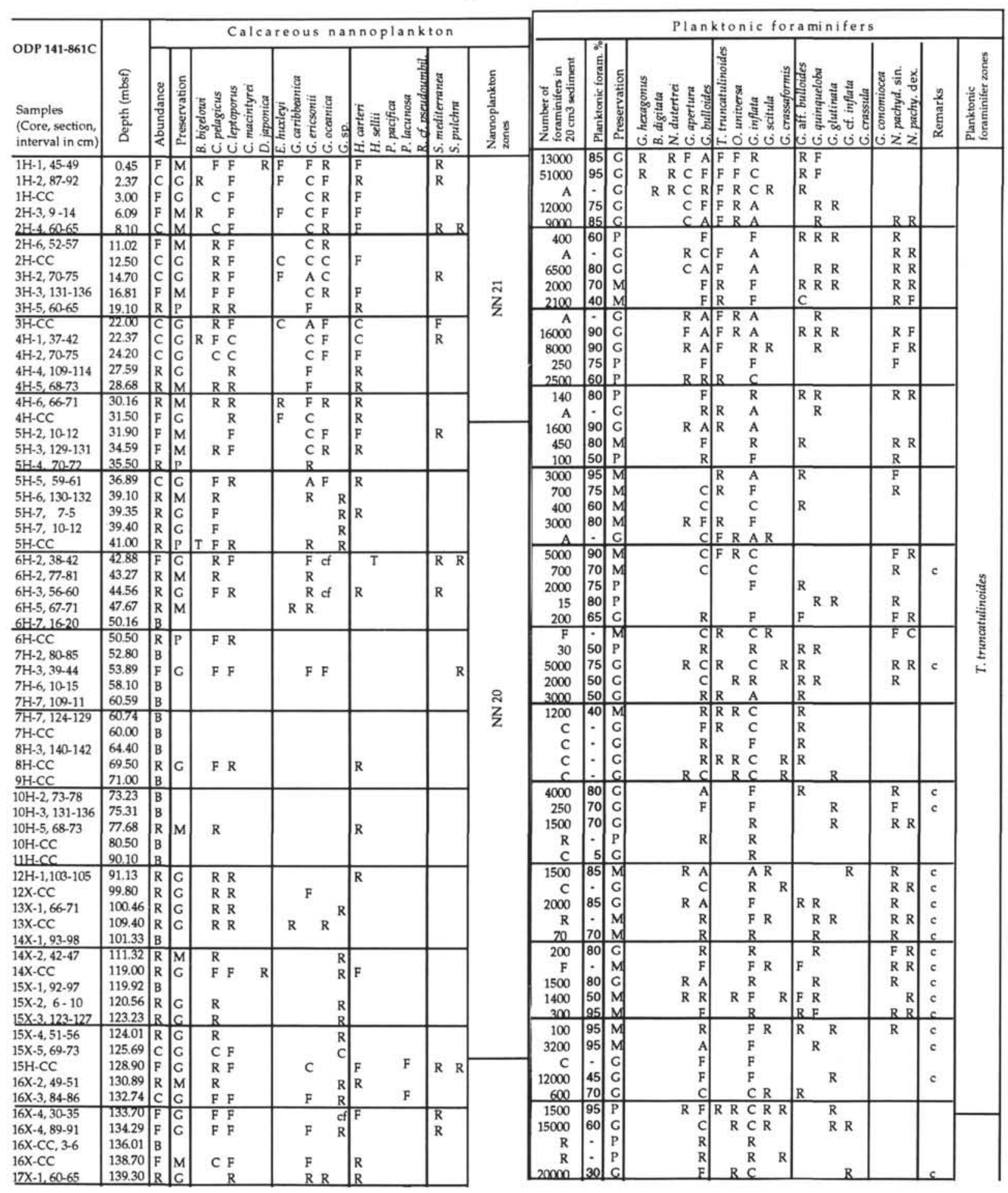

\section{SUMMARY}

Age determination of the sediments recovered during Leg 141 are difficult owing to the scarcity of the calcareous fossils and the low diversified assemblages. However, it was possible to establish a correlation between the calcareous nannoplankton and planktonic foraminifer zones (Fig. 4), except for Site 860, which contains some ambiguities and contradictions. It was not possible to confirm by calcareous nannofossils the imbrications and repetitions of upper and lower Pliocene sediments in Hole 141-860B below 120 mbsf as stated by planktonic foraminifers.

Based on calcareous nannoplankton, the Quaternary was broadly subdivided into the upper and lower Pleistocene by using the Zone NN20/NN19 boundary. The Pleistocene is represented by the T. truncatulinoides foraminifer Zone.

The Pliocene/Pleistocene boundary at $1.6 \mathrm{Ma}$ was determined by the FO of specimens of the Gephyrocapsa oceanica group and the FO of $T$. truncatulinoides, respectively. Owing to paleoenvironmental 
Table 7 (continued).

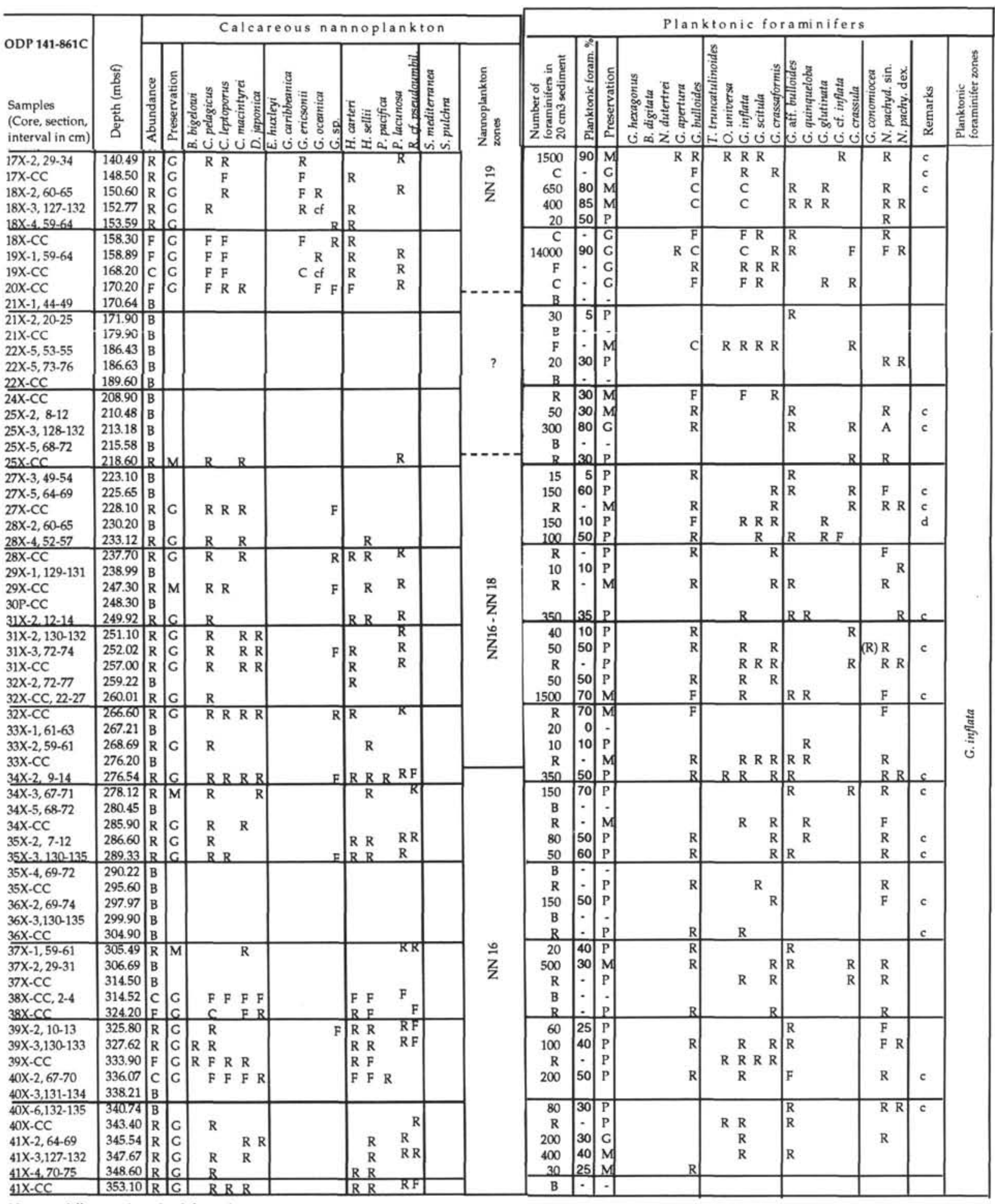

conditions this occurrence may not always represent the real biostratigraphic event, and the determination of the boundary by using different fossil groups is difficult, and it does not fall in all cases at the same level.

A subdivision of the upper Pliocene sequences is impossible owing to low diversified fossil assemblages. The upper Pliocene is represented by the stratigraphic interval of nannoplankton Zones NN16 to NN18, which corresponds to the foraminiferal zone of $G$. inflata, and ranges in age from 3.2 to $1.6 \mathrm{Ma}$. The base of the upper Pliocene corresponds to the Zone NN15/NN16 boundary, which is placed together with the $G$. crassaformis $/ G$. inflata foraminiferal Zone boundary at $3.2 \mathrm{Ma}$ (Fig. 5).

The scarcity of the calcareous micro- and nannofossils may be related to dissolution owing to deposition below the CCD or to pressure solution effects within the wedge caused by tectonic deformation. Another factor is dilution by the large amount of detrital material. The 
Table 8. Distribution of calcareous nannoplankton and planktonic foraminifers in Hole 861D.

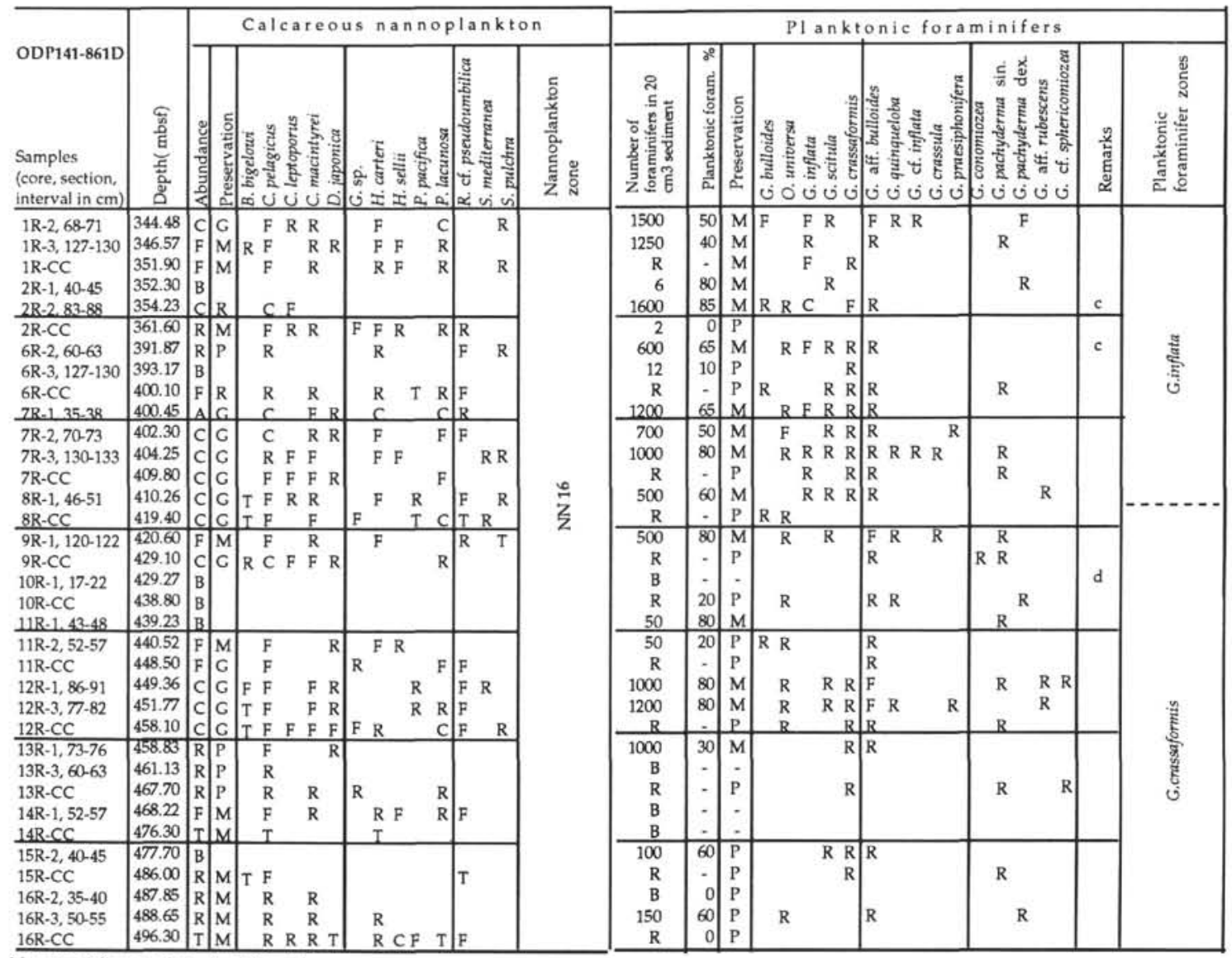

Note: $c=$ different colors, $\mathrm{d}=$ deformed

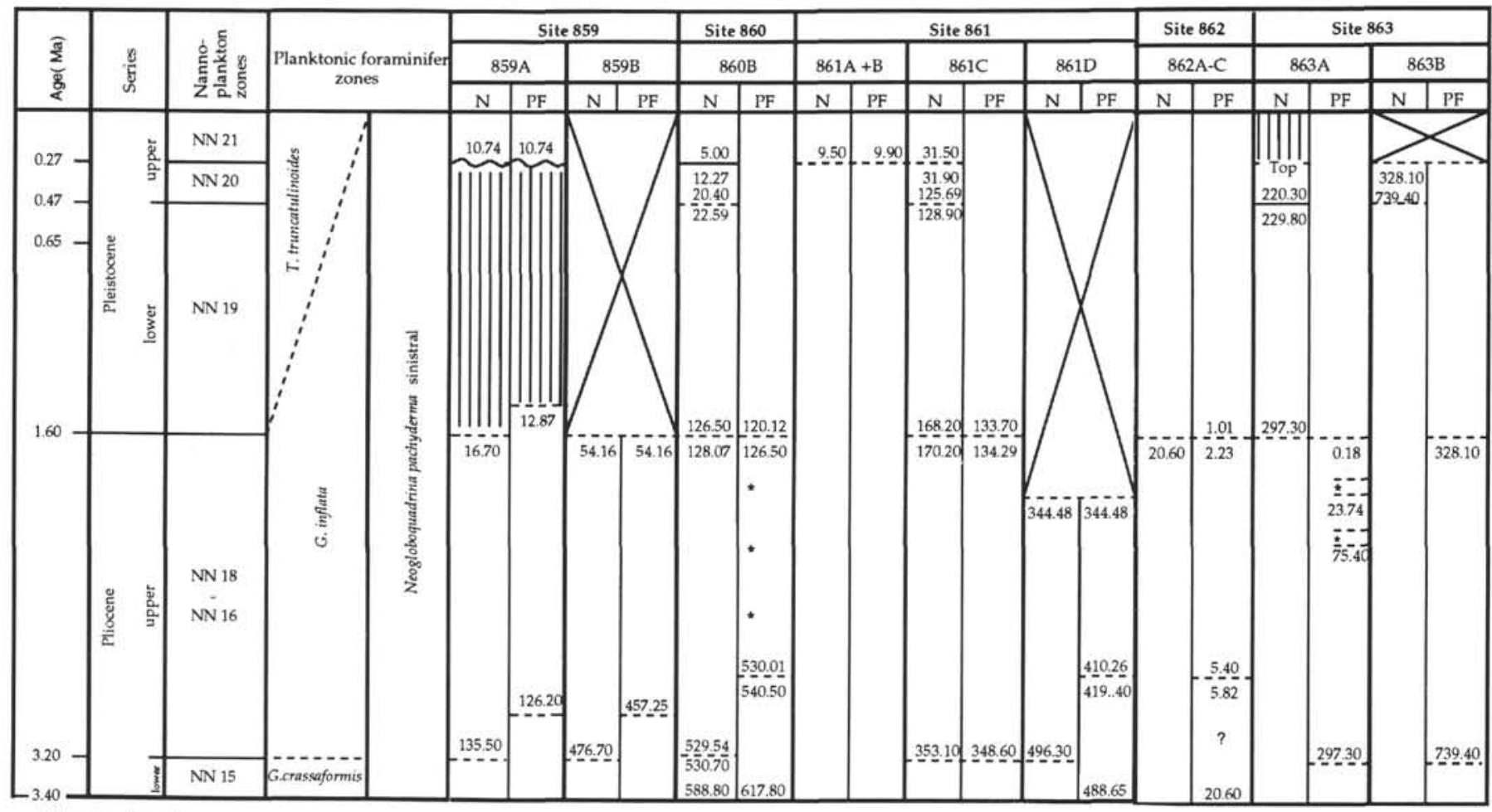

$\cdot=$ displaced sediments

Figure 4. Biostratigraphy of Sites 859 through 863 based on calcareous nannoplankton (N) and planktonic foraminifers (PF). 
Table 9. Distribution of calcareous nannoplankton and planktonic foraminifers in Holes 862A, 862B, and 862C.

\begin{tabular}{|c|c|c|c|c|c|c|c|c|c|c|c|c|c|}
\hline \multirow[b]{2}{*}{$\begin{array}{l}\text { ODP 141- } \\
\text { 862A } \\
\text { Samples } \\
\text { (Core, section, } \\
\text { interval in cm) }\end{array}$} & \multirow[b]{2}{*}{ 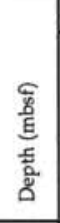 } & \multicolumn{4}{|c|}{ Calcareous nannoplankton } & \multicolumn{8}{|c|}{ Planktonic foraminifers } \\
\hline & & 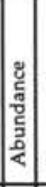 & 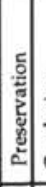 & 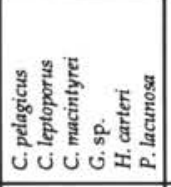 & 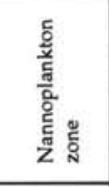 & 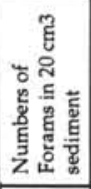 & 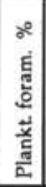 & 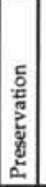 & 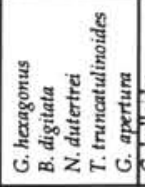 & 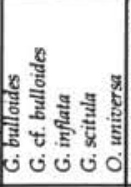 & 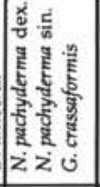 & 里 & 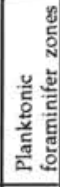 \\
\hline $\begin{array}{l}\mathrm{H}-1,14-18 \\
1 \mathrm{H}-1,18-21 \\
1 \mathrm{H}-1,62-64 \\
1 \mathrm{H}-1,88-91 \\
1 \mathrm{H}-1,101-104\end{array}$ & $\begin{array}{l}0.14 \\
0.18 \\
0.62 \\
0.88 \\
1.01\end{array}$ & \begin{tabular}{|l|}
$\mathrm{B}$ \\
$\mathrm{B}$ \\
$\mathrm{B}$ \\
$\mathrm{B}$ \\
$\mathrm{B}$ \\
\end{tabular} & & & & $\begin{array}{r}1000 \\
1000 \\
100 \\
8 \\
50 \\
\end{array}$ & $\begin{array}{l}95 \\
95 \\
80 \\
- \\
80 \\
\end{array}$ & \begin{tabular}{l|}
$G$ \\
$C$ \\
$M$ \\
$P$ \\
$M$
\end{tabular} & $\begin{array}{|lllll|}R & R & R & F & R \\
R & R & R & R & F \\
& & & & \\
& & & & \\
& & & R & \\
\end{array}$ & 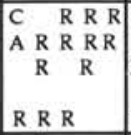 & \begin{tabular}{|ll}
$R$ & \\
$R$ & $R$ \\
$R$ & $R$ \\
$R$ & $R$ \\
$R$ & $R$ \\
\end{tabular} & & 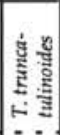 \\
\hline $\begin{array}{l}1 \mathrm{H}-2,73-76 \\
1 \mathrm{H}-2,131-134 \\
1 \mathrm{H}-4,31-34 \\
1 \mathrm{H}-\mathrm{CC} \\
2 \mathrm{H}-1,42-43\end{array}$ & $\begin{array}{l}2.23 \\
2.81 \\
4.81 \\
5.40 \\
5.82 \\
\end{array}$ & \begin{tabular}{|l|l}
$\mathrm{T}$ & $\mathrm{D}$ \\
$\mathrm{B}$ & \\
$\mathrm{B}$ & \\
$\mathrm{B}$ & \\
$\mathrm{B}$ & \\
\end{tabular} & \begin{tabular}{l|l}
$\mathrm{M}$ & 1 \\
& \\
& \\
\end{tabular} & $\mathrm{~T} \mathrm{~T}$ & & $\begin{array}{r}250 \\
500 \\
25 \\
5 \\
100 \\
\end{array}$ & $\begin{array}{l}90 \\
90 \\
10 \\
- \\
60 \\
\end{array}$ & \begin{tabular}{l|}
$\mathrm{G}$ \\
$\mathrm{M}$ \\
$\mathrm{M}$ \\
$\mathrm{M}$ \\
$\mathrm{P}$
\end{tabular} & & $\begin{array}{|ll|}R & \\
R & R \\
R & R \\
\end{array}$ & \begin{tabular}{|lll}
$F$ & $F$ & \\
$F$ & $C$ & $R$ \\
& $F$ \\
$R$ & \\
$C$
\end{tabular} & c & \\
\hline $\begin{array}{l}\text { 2H-1, 95-97 } \\
2 \mathrm{H}-4,103-105 \\
2 \mathrm{H}-5,80-82 \\
2 \mathrm{H}-6,111-113 \\
2 \mathrm{H}-\mathrm{CC}\end{array}$ & \begin{tabular}{c|}
6.35 \\
10.93 \\
12.20 \\
14.01 \\
14.90 \\
\end{tabular} & \begin{tabular}{|c|}
$\mathrm{B}$ \\
$\mathrm{B}$ \\
$\mathrm{B}$ \\
$\mathrm{T}$ \\
$\mathrm{B}$ \\
\end{tabular} & $\mathrm{M}$ & $\mathrm{T}$ & & $\begin{array}{r}3 \\
50 \\
0 \\
15 \\
0 \\
\end{array}$ & \begin{tabular}{c|} 
\\
95 \\
- \\
95
\end{tabular} & \begin{tabular}{l|}
$\mathrm{G}$ \\
$\mathrm{P}$ \\
$\mathrm{P}$
\end{tabular} & & & $\begin{array}{r}R \\
R \text { F } \\
R\end{array}$ & c & 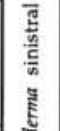 \\
\hline $\begin{array}{l}3 \mathrm{H}-1,38-41 \\
3 \mathrm{H}-2,60-63 \\
3 \mathrm{H}-4,48-51 \\
3 \mathrm{H}-4,85-88 \\
3 \mathrm{H}-4,106-109 \\
\end{array}$ & $\begin{array}{l}15.28 \\
17.00 \\
19.88 \\
20.25 \\
20.46 \\
\end{array}$ & \begin{tabular}{|l|}
$\mathrm{B}$ \\
$\mathrm{B}$ \\
$\mathrm{B}$ \\
$\mathrm{B}$ \\
$\mathrm{B}$ \\
\end{tabular} & & & & $\begin{array}{l}1 \\
5 \\
1 \\
0 \\
0 \\
\end{array}$ & $\begin{array}{l}- \\
0 \\
- \\
\end{array}$ & & & & $R_{R}^{R}$ & & 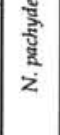 \\
\hline $\begin{array}{l}\mathrm{H}-\mathrm{CC} \\
4 \mathrm{H}-\mathrm{CC}\end{array}$ & $\begin{array}{l}20.60 \\
21.10 \\
\end{array}$ & \begin{tabular}{|l|}
$\mathrm{F}$ \\
$\mathrm{B}$
\end{tabular} & \begin{tabular}{|l|l|}
$\mathrm{M}$ & $\mathrm{F}$ \\
\end{tabular} & F R TR R R & NN16-18 & $\begin{array}{c}100 \\
0\end{array}$ & 90 & M & & $R$ & RR & c & \\
\hline \multicolumn{14}{|l|}{$\begin{array}{l}\text { ODP 141- } \\
862 B\end{array}$} \\
\hline $\begin{array}{l}2 X-1,96-98 \\
2 X-C C\end{array}$ & $\begin{array}{l}18.46 \\
27.10\end{array}$ & $\mathrm{~B}$ & & & & $\begin{array}{c}0 \\
15\end{array}$ & 90 & $\mathrm{M}$ & & & R & & 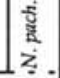 \\
\hline \multicolumn{14}{|l|}{$\begin{array}{l}\text { ODP 141- } \\
862 C\end{array}$} \\
\hline $\begin{array}{r}1 W-1.10-12 \\
1 W-1.32-39 \\
6 R-1,37-39 \\
\end{array}$ & Piece 6 & $\begin{array}{l}\text { B } \\
\text { B } \\
\text { B }\end{array}$ & & & & $\begin{array}{r}25 \\
50 \\
0\end{array}$ & $\begin{array}{r}10 \\
5\end{array}$ & G & & ${ }^{R}$ & ${ }_{R}^{R}$ & & $\begin{array}{l}\overleftarrow{\mathrm{K}} \\
\dot{z} \\
\dot{z}\end{array}$ \\
\hline
\end{tabular}

Note: $\mathrm{c}=$ different colors.

generally poorly diversified assemblages can also be explained by cold surface-water. However, the fossil assemblages observed within the uppermost meters of the sequences indicate the influence of warmer surface-water off southern Chile in further times. Planktonic foraminifers from Leg 141 sites are documented on Plate 1.

\section{ACKNOWLEDGMENTS}

We thank the Deutsche Forschungsgemeinschaft (Bonn/Bad Godesberg) for supporting this study and J.H. Behrmann, D.G. Jenkins, E. Martini, and R.S. Musgrave for reviewing the manuscript.

\section{REFERENCES $*$}

Bé, A.W.H., and Tolderlund, D.S., 1971. Distribution and ecology of living planktonic foraminifera in surface waters of the Atlantic and Indian Oceans. In Funnel, B.M., and Riedel, W.R. (Eds.), The Micropaleontology of Oceans: Cambridge (Cambridge Univ. Press), 105-149.

Behrmann, J.H., Lewis, S.D., Musgrave, R.J., et al., 1992. Proc. ODP, Init. Repts., 141: College Station, TX (Ocean Drilling Program).

Bizon, G., and Müller, C., 1977. Remarks on some biostratigraphic problems in the Mediterranean Neogene. In Biju-Duval, B., and Montadert, L. (Eds.), Structural History of the Mediterranean Basins: Split, Yugoslavia (Tecnoprint), 381-390.

Kennett, J.P., and Srinivasan, M.S., 1983. Neogene Planktonic Foraminifera: A Phylogenetic Atlas: Stroudsburg, PA (Hutchinson Ross).
Martini, E., 1971. Standard Tertiary and Quaternary calcareous nannoplankton zonation. In Farinacci, A. (Ed.), Proc. 2nd Int. Conf. Planktonic Microfossils Roma: Rome (Ed. Tecnosci.), 2:739-785.

Martini, E., and Müller, C., 1986. Current Tertiary and Quaternary calcareous nannoplankton stratigraphy and correlations. Newsl. Stratigr., 16:99-112.

Müller, C., 1979. Calcareous nannofossils from the North Atlantic (Leg 48). In Montadert, L., Roberts, D.G., et al., Init. Repts. DSDP, 48: Washington (U.S. Govt. Printing Office), 589-639.

Raffi, I., and Rio, D., 1979. Calcareous nannofossil biostratigraphy of DSDP Site 132-Leg 13 (Tyrrhenian Sea-Western Mediterranean). Riv. Ital. Paleontol. Stratigr., 85:127-172.

Srinivasan, M.S., and Kennett, J.P., 1981. A review of Neogene planktonic foraminiferal biostratigraphy: applications in the equatorial and South Pacific. In Warme, J.E., Douglas, R.G., and Winterer, E.L. (Eds.), The Deep Sea Drilling Project: A Decade of Progress. Spec. Publ.-Soc. Econ. Paleontol. Mineral., 32:395-432.

\footnotetext{
Abbreviations for names of organizations and publications in ODP reference lists follow the style given in Chemical Abstracts Service Source Index (published by American Chemical Society)
}

Date of initial receipt: 23 July 1993

Date of acceptance: 1 June 1994

Ms 141SR-009 
Table 10. Distribution of calcareous nannoplankton and planktonic foraminifers in Hole 863A.

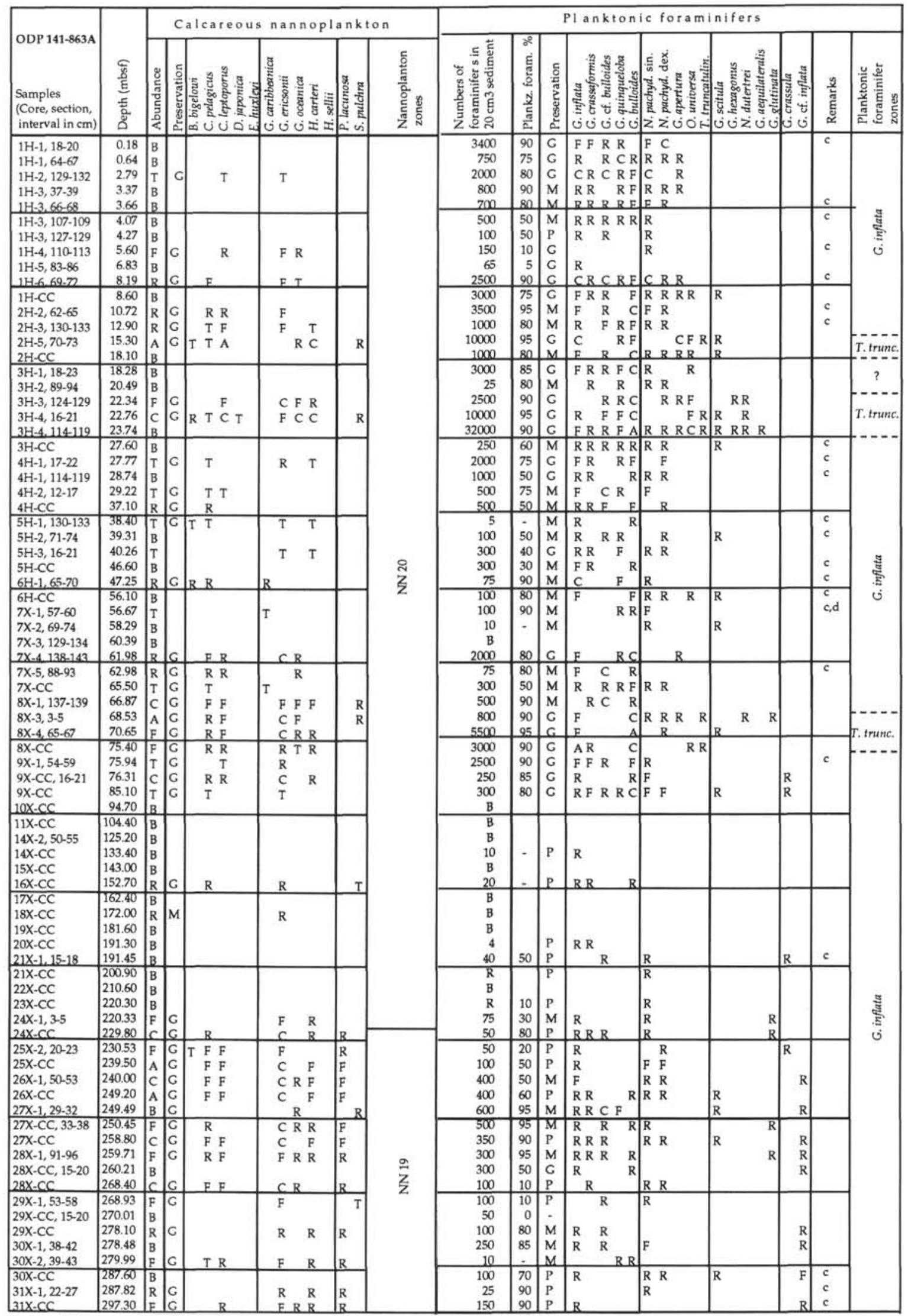

Note: $\mathrm{c}=$ different colors, $\mathrm{d}=$ deformed. 
Table 11. Distribution of calcareous nannoplankton and planktonic foraminifers in Hole 863B.

\begin{tabular}{|c|c|c|c|c|c|c|c|c|c|c|c|c|c|c|}
\hline \multirow[b]{2}{*}{$\begin{array}{l}\text { ODP 141-863B } \\
\text { Samples } \\
\text { (core, section, } \\
\text { interval in } \\
\mathrm{cm} \text { ) }\end{array}$} & \multirow[b]{2}{*}{ 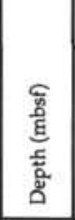 } & \multicolumn{5}{|c|}{ Calcareous nannoplankton } & \multicolumn{8}{|c|}{ Planktonic foraminifers } \\
\hline & & 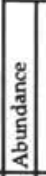 & 횡. & 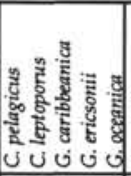 & 형 & 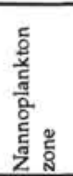 & 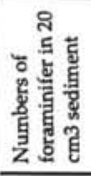 & 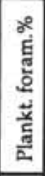 & 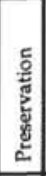 & 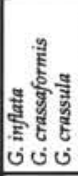 & 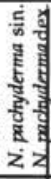 & 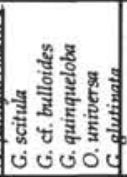 & 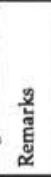 & 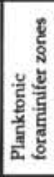 \\
\hline $4 X-2,70-73$ & 328.10 & $F$ & \begin{tabular}{l|l}
$\mathrm{G}$ & $\mathrm{T}$ \\
\end{tabular} & $\begin{array}{|ll|}T & F \\
\end{array}$ & & \multirow{71}{*}{ 艺 } & 50 & 85 & $\mathrm{M}$ & F $\quad \mathrm{R}$ & $\mathrm{R}$ & & & \\
\hline $4 X-3,52-55$ & 329.42 & $\mathbf{R}$ & G) & $\mathbf{R}$ & & & 50 & 60 & $\mathrm{M}$ & R & & R R R & & \\
\hline $4 X-5,48-51$ & 332.38 & $\mathrm{~F}$ & C $\mathrm{F}$ & R R & & & 10 & & & & $\mathrm{R} R$ & & & \\
\hline $\begin{array}{l}4 \mathrm{X}-\mathrm{CC} \\
5 \mathrm{X}-\mathrm{CC}\end{array}$ & 335.60 & F & G). & & & & 25 & - & P & R R & & & & \\
\hline $5 \times-c c$ & 34520 & $\mathrm{~F}$ & a & $R$ & $\mathrm{R}$ & & 20 & - & $\mathrm{P}$ & $R$ & $\mathrm{R}$ & R & & \\
\hline $6 x-C C$ & 354.90 & $\mathrm{~F}$ & C $\mathrm{F}$ & R R & & & 300 & 90 & $M$ & $R R$ & $\mathrm{~F}$ & $\mathrm{R}$ & $\mathbf{s}$ & \\
\hline $7 X-1,71-73$ & 355.61 & $\mathrm{~F}$ & G $F$ & F R & & & 500 & 95 & M & F $\quad R$ & $\mathbf{F}$ & $\mathrm{R}$ & $s$ & \\
\hline $7 \mathrm{X}-\mathrm{CC}$ & 357.40 & B & 1 & & & & 10 & - & $\mathrm{P}$ & & & & & \\
\hline $8 \mathrm{X}-\mathrm{CC}$ & 361.40 & c & G $\mathrm{F}$ & C & $\mathbf{R}$ & & 0 & & & & & & & \\
\hline $9 \mathrm{X}-\mathrm{CC}$ & 371.00 & c & G $\mathrm{P}$ & C & $\mathbf{R}$ & & 0 & & & & & & & \\
\hline $\begin{array}{l}\text { 10R-1, 45-48 } \\
\text { 1OR-CC }\end{array}$ & \begin{tabular}{|l|}
371.45 \\
376.60
\end{tabular} & $\begin{array}{l}\mathrm{R} \\
\mathrm{B}\end{array}$ & C & $\mathrm{R}$ & & & $\begin{array}{r}25 \\
0\end{array}$ & - & M & R R & & & & \\
\hline $11 \mathrm{R}-1,47-49$ & 377.07 & $\mathrm{~F}$ & $G F$ & R R & & & 2500 & 95 & G & F & A & R R & c & \\
\hline 11R-CC & 386.30 & $\begin{array}{l}B \\
B\end{array}$ & & & & & 0 & & & & & & & \\
\hline$\frac{12 \mathrm{R}-\mathrm{CC}}{13 \mathrm{R}-1,46-48}$ & 396.26 & $\frac{p}{R}$ & $\mathrm{G} / \mathrm{F}$ & $\mathbf{R}$ & & & $\frac{2}{3}$ & - & & & & & $\frac{s}{s}$ & \\
\hline $13 R-C C$ & 405.50 & $\mathrm{~B}$ & & & & & 0 & & & & & & 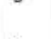 & \\
\hline 14R-CC & 415.20 & B & & & & & 4 & & $P$ & R & & & s & \\
\hline $15 R-C C$ & 424.70 & $F$ & $\mathrm{Cl} F$ & R & & & 10 & & & $\mathrm{R}$ & & & d & \\
\hline 16R-CC & 434.40 & $\mathrm{~F}$ & G $\mathrm{F}$ & R R $R \quad F$ & & & 20 & & $\mathrm{M}$ & $\mathrm{F} \mathrm{R}$ & $\mathrm{R}$ & & $s$ & \\
\hline $17 \mathrm{R}-2,46-49$ & 436.36 & $F$ & G/F & $\begin{array}{|ll|}\text { RR } & \text { F } \\
\end{array}$ & & & 13000 & 90 & $\mathrm{P}$ & C F & $\mathrm{R}$ & C & $s, d$ & \\
\hline $17 R-4,14-16$ & 439.04 & B & & & & & 1500 & 90 & P & & R R & C & s & \\
\hline $17 R-6,3-7$ & 441.93 & c & $\mathrm{G} F$ & F R R C & & & 6000 & 80 & $\mathrm{p}$ & F R & $\mathrm{F}$ & C & s,d & \\
\hline $17 \mathrm{R}-\mathrm{CC}$ & 444.00 & c & $\mathrm{G} / \mathrm{F}$ & R F C & & & 0 & & & & & & & \\
\hline $18 R-1,100-104$ & 445.00 & c & c. $\mathrm{F}$ & $F \quad R \quad C R$ & & & 10000 & 90 & $P$ & C ER & $R R$ & A & $s, d$ & \\
\hline $18 \mathrm{R}-3,82-86$ & 447.82 & C & G F & \begin{tabular}{|lll} 
F & R & C \\
\end{tabular} & & & 2500 & 90 & $P$ & F R R & $\mathrm{R}$ & A & s,d & \\
\hline $18 \mathrm{R}-\mathrm{CC}$ & 453.70 & $\mathrm{~F}$ & $\mathrm{G} / \mathrm{F}$ & R R F F & & & 80 & 100 & $\mathrm{P}$ & R & $\mathrm{R}$ & & $\mathrm{s}$ & \\
\hline $19 \mathrm{R}-3,80-83$ & 457.50 & c & $\mathrm{Cl}$ & $R R \subset F R$ & & & 250 & 90 & M & $F$ & $\mathrm{R}$ & $\mathbf{R}$ & s,d & \\
\hline 19R-CC & 463.40 & c & G $\mathrm{F}$ & R R F C R & & & 200 & 90 & $\mathrm{M}$ & F R & $\mathrm{R}$ & & $\mathrm{s}, \mathrm{d}$ & \\
\hline $20 \mathrm{R}-2,83-85$ & 465.59 & F & $\mathrm{GH}$ & R F F F & & & 300 & 90 & $\mathrm{P}$ & $\mathrm{F}$ & & R R & s & \\
\hline $20 \mathrm{R}-\mathrm{CC}$ & 473.00 & $R$ & $M$ & FR & & & 10 & 90 & $\mathrm{P}$ & $\overline{R R}$ & & & $\mathrm{~s}$ & \\
\hline 21R-CC & 482.70 & $\mathrm{~F}$ & G $\mathrm{F}$ & R R F F & & & 25 & 20 & P & R & & & s & \\
\hline 22R-CC & 492.40 & c & G $\mathrm{F}$ & R R F C R & & & 50 & 80 & $\mathrm{P}$ & F R & $\mathbf{R}$ & & s & \\
\hline $23 \mathrm{R}-4,79-83$ & 497.69 & c & $\mathrm{C} F$ & R R $R \quad F \quad R$ & R & & 50 & 80 & P & R R & $\mathbf{R}$ & R R & $\mathbf{s}$ & हैँ \\
\hline $23 \mathrm{R}-\mathrm{CC}$ & 502.00 & B & & & & & 3 & - & $\mathrm{P}$ & R R & & $\mathrm{R}$ & $\mathrm{s}$ & $\mathrm{E}$ \\
\hline $24 \mathrm{R}-\mathrm{CC}$ & 511.70 & $B$ & & & & & 1 & - & $\mathrm{P}$ & $\mathrm{R}$ & & & $\mathrm{s}$ & ن \\
\hline $25 \mathrm{R}-\mathrm{CC}$ & 521.40 & $\mathrm{~F}$ & $\mathrm{G} / \mathrm{F}$ & R R F F R & & & 20 & 50 & P & R & & $\mathrm{R}$ & s & \\
\hline $26 \mathrm{R}-1,7-9$ & 521.47 & c & c) & C $\quad F R$ & $\mathrm{~F}$ & & 10 & - & $\mathrm{P}$ & R & & $\mathrm{R}$ & & \\
\hline $26 \mathrm{R}-2,50-53$ & 522,45 & c & $\mathrm{GC}$ & C R C & $\mathrm{F}$ & & 200 & 80 & $\mathrm{P}$ & $R$ & R & C & $s, d$ & \\
\hline $26 \mathrm{R}-\mathrm{CC}$ & 53060 & c & alp & F R F C & & & 25 & 50 & $\mathrm{P}$ & R & & $\mathrm{R} \quad \mathrm{R}$ & $s, d$ & \\
\hline 27R-01, 71-74 & 531.31 & $B$ & & & & & 25 & 80 & $P$ & R R & $R$ & & s & \\
\hline $27 \mathrm{R}-\mathrm{CC}$ & 540.20 & B & & & & & 30 & 50 & $P$ & & & & & \\
\hline 28R-CC & 549.70 & c & G & R R F C R & R R & & 1 & - & G & $\mathrm{R}$ & & & & \\
\hline $29 \mathrm{R}-\mathrm{CC}$ & 559.40 & c & C 1 & R R F C R & R & & 50 & 90 & G & F R & & $\mathbf{R}$ & $\mathbf{s}$ & \\
\hline 30R-CC & 569.10 & c & G $\mathrm{B}$ & F R F C R & & & 1000 & 90 & G & F R R & & R R & $s$ & \\
\hline 31R-CC & 578.80 & C & GIF & RRFCR & R & & 25 & 90 & $\mathrm{P}$ & R R & & & $\mathrm{s}$ & \\
\hline $32 R-C C$ & 588.40 & B & G & & & & 10 & 0 & P & & & & s & \\
\hline 33R-CC & 598.10 & $\mathrm{~F}$ & & R R F F & $\mathrm{R} R$ & & 10 & - & $\mathrm{P}$ & $R$ & $\mathrm{R}$ & & $\mathbf{s}$ & \\
\hline $34 \mathrm{R}-\mathrm{CC}$ & 607.70 & B & c & & & & 0 & & & R & & & & \\
\hline $35 R-6,45-47$ & 615.65 & $F$ & & R R F F & $\mathrm{R}$ & & 5 & - & $P$ & $\mathrm{R}$ & & $\mathrm{R}$ & $s$ & \\
\hline $35 \mathrm{R}-\mathrm{CC}$ & 617.40 & B & G & & & & 0 & & & & & & & \\
\hline 36R-CC & 627.00 & $\mathrm{~F}$ & C $\mathrm{F}$ & R R F F R & & & 2 & - & $P$ & R & $\mathbf{R}$ & & & \\
\hline 37R-CC & 636.60 & $R$ & G & $\mathrm{R}$ & & & 2 & - & P & R & & & $\mathrm{s}$ & \\
\hline 38R-CC & 646.30 & c & G 1 & R R F C R & & & 0 & & & & & & & \\
\hline $39 \mathrm{R}-\mathrm{CC}, 4-10$ & 650.34 & B & & & & & 100 & 80 & $\mathrm{P}$ & $\mathrm{R}$ & & $\mathrm{R}$ & $\mathrm{s}, \mathrm{d}$ & \\
\hline $39 \mathrm{R}-\mathrm{CC}$ & 655.90 & $\mathrm{~F}$ & G। & RR & & & 50 & - & $\mathrm{P}$ & $\mathrm{R}$ & RR & $\mathrm{R}$ & s & \\
\hline $40 \mathrm{R}-1,45-48$ & 656.35 & $\mathrm{R}$ & c] & R & & & 200 & 80 & $\mathrm{P}$ & F R & $\mathrm{F}$ & $\mathrm{F}$ & $s, d$ & \\
\hline 40R-3, 84-88 & 659.44 & $R$ & $\mathrm{M}$ & $\mathbf{R}$ & & & 200 & & $\mathrm{M}$ & F R & $\mathrm{F}$ & $\mathrm{F}$ & $s, d$ & \\
\hline 40R-CC & 665.50 & $\mathrm{~F}$ & G] & F & & & 100 & 80 & $\mathrm{P}$ & R R & R & & s & \\
\hline $41 R-2,92-95$ & 667.92 & $\mathrm{R}$ & G & $\mathrm{R}$ & $\mathrm{R}$ & & 150 & 80 & $P$ & $\mathrm{~F}$ & $\mathrm{R}$ & & $\mathrm{s}$ & \\
\hline $41 R-4,32-36$ & 670.32 & $F$ & G & R R F & & & 250 & 90 & $\mathrm{P}$ & $\mathrm{C}$ & & $\bar{R}$ & $\mathrm{~s}, \mathrm{~d}$ & \\
\hline 41R-CC & 675.20 & c & G $\mathrm{F}$ & R R F C & & & 100 & 95 & $\mathrm{P}$ & F R & $\mathrm{R}$ & & s & \\
\hline $42 \mathrm{R}-\mathrm{CC}$ & 684.80 & c & $\mathrm{CH}$ & $R$ R C C R & $R$ & & 100 & 95 & $\mathrm{P}$ & F R & & & s & \\
\hline $43 R-3,47-52$ & 687.77 & $\mathrm{~F}$ & C. & $\begin{array}{ll}R & F\end{array}$ & & & 50 & 90 & $P$ & R & $\mathbf{R}$ & & $\mathrm{s}, \mathrm{d}$ & \\
\hline $43 R-C C$ & 694.50 & c & c] & $\mathrm{R} R C \mathrm{C}$ & $\mathrm{R}$ & & 150 & 95 & $\mathrm{M}$ & c & & $\mathrm{R}$ & s & \\
\hline $44 \mathrm{R}-\mathrm{CC}$ & 704.20 & C & C 1 & R R C C & & & 5 & - & $\mathrm{P}$ & $R$ & & $\bar{R}$ & $\mathrm{~s}$ & \\
\hline 45R-CC & 706.80 & c & C $\mathrm{F}$ & R F C C & & & 4 & - & $P$ & $\mathrm{R}$ & & & s & \\
\hline 46R-CC & 713.80 & c & C $\mathrm{F}$ & $R$ R C C R & $R$ & & 0 & & & & & & & \\
\hline $47 \mathrm{R}-\mathrm{CC}$ & 723.50 & c & C. & R R C C & & & 0 & & & & & & & \\
\hline 48R-CC, $20-22$ & 725.69 & C & G & $F F \quad C R$ & & & 100 & 90 & $\mathrm{P}$ & $\mathrm{R}$ & $\mathrm{R}$ & $\mathbf{R}$ & 8 & \\
\hline $48 \mathrm{R}-\mathrm{CC}$ & 733.20 & c & G & RRCC & & & 50 & 90 & $\mathrm{P}$ & $F$ & & $\mathrm{R}$ & $\mathrm{s}$ & \\
\hline $49 \mathrm{R}-1,19-22$ & 733.39 & c & $c \mid r$ & F F $\quad C$ & $R$ & & 100 & 90 & $\mathrm{P}$ & F R & $\mathrm{F}$ & $\mathrm{R}$ & s & \\
\hline 49R-CC & 739.40 & c & $\mathrm{Cl}$ & R R C A R & & & 100 & 80 & $M$ & F R & & $\mathrm{R}$ & $\mathrm{s}$ & \\
\hline
\end{tabular}

Note: $c=$ different colors, $d=$ deformed, $s=$ silicified. 
D. SPIEGLER, C. MÜLLER

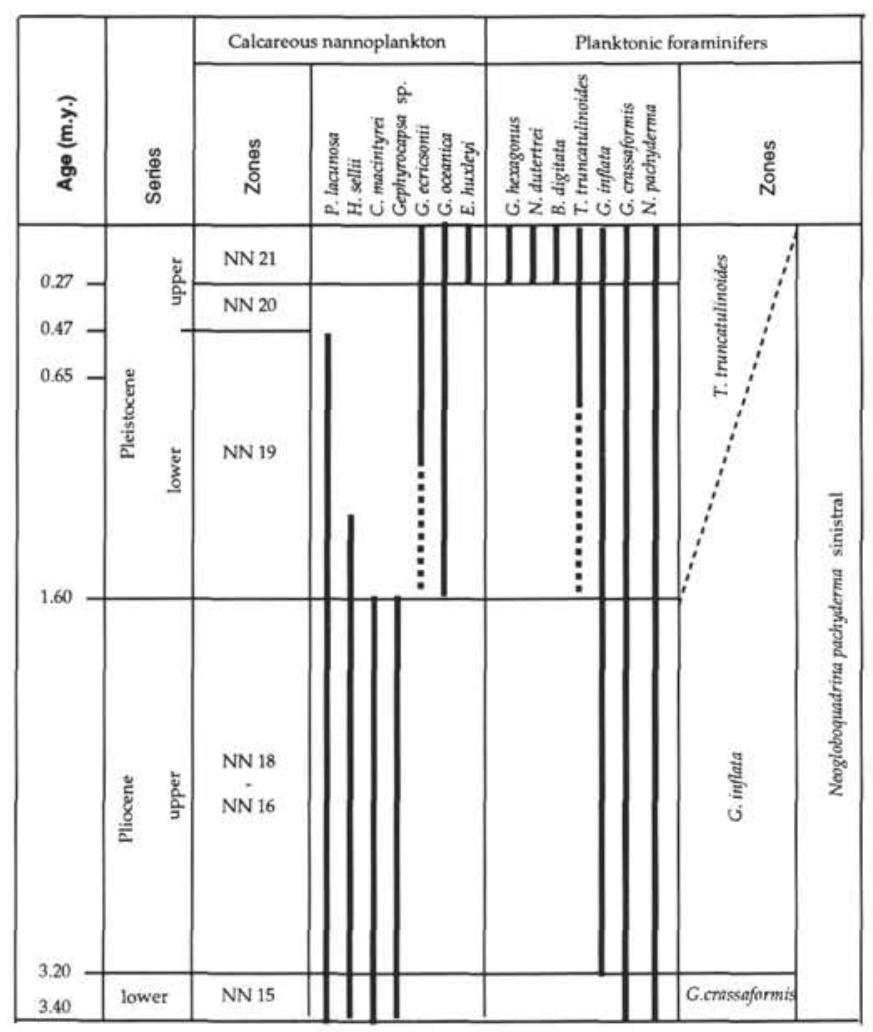

Figure 5. Range chart of Leg 141 index species. 

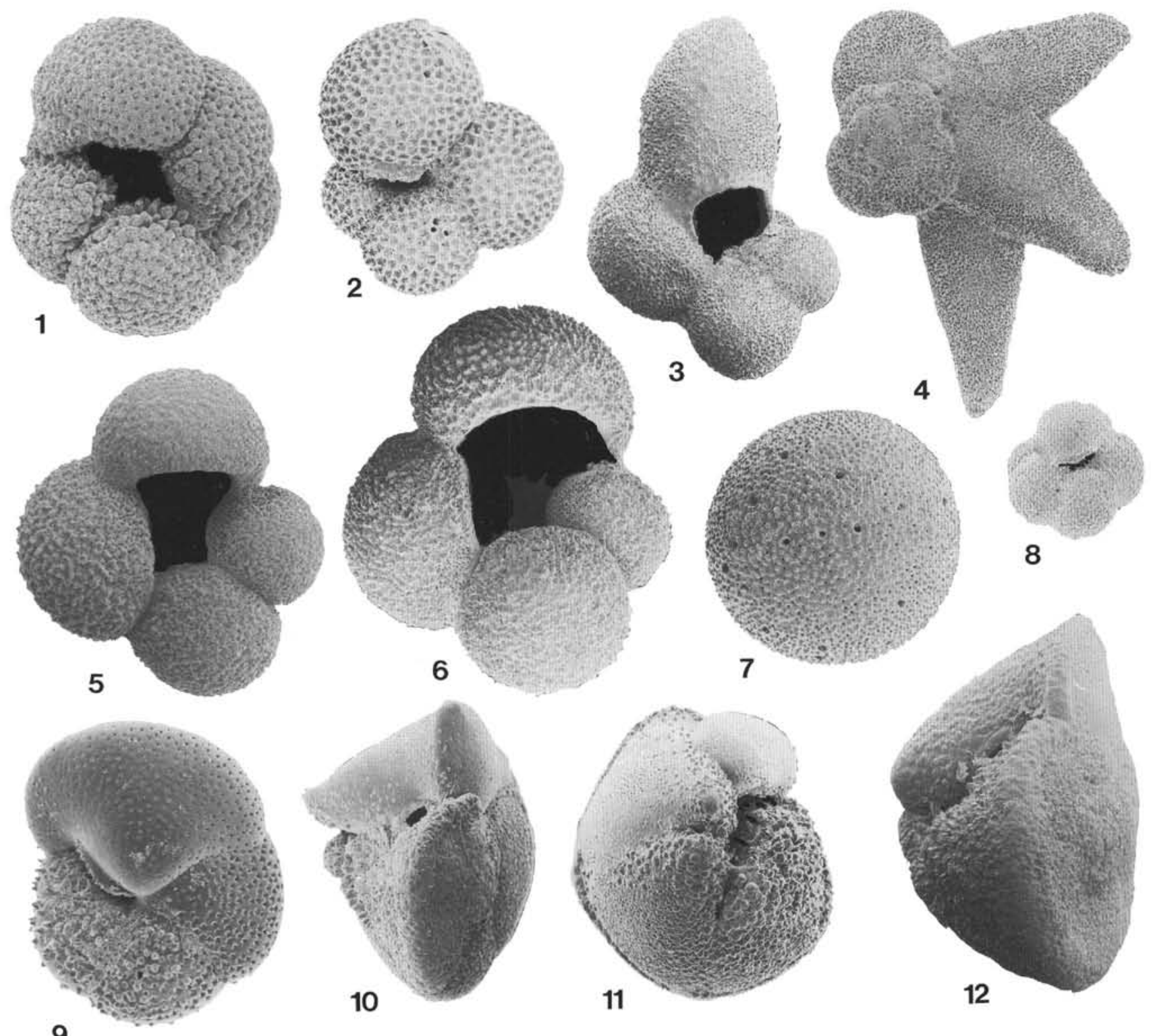

8
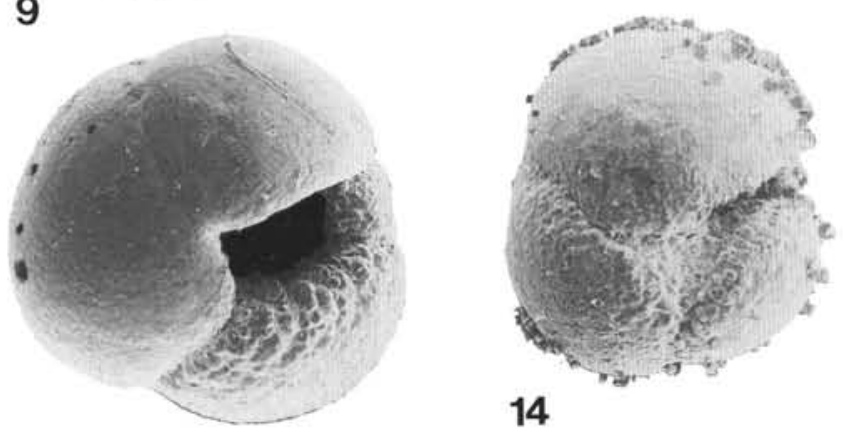

14
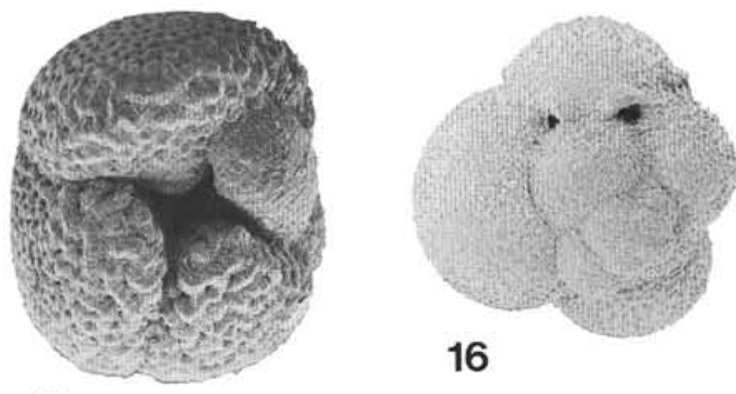

15

13

Plate 1. Pleistocene planktonic foraminifers from Leg 141 sites. 1. Neogloboquadrina dutertrei (Orbigny, 1839); Sample 141-861C-1H-1, 45-49 cm. 2. Globorotaloides hexagonus (Natland, 1938); Sample 141-862A-1H-1, 14-18 cm. 3, 4. Beella digitata (Brady, 1879). (3) Sample 141-861C-1H-CC, (4) Sample 141-862A-1H-1, 18-21 cm. 5. Globigerina bulloides Orbigny, 1826; Sample 141-861C-1H-1, 45-49 cm. 6. Globigerina apertura Cushman, 1918; Sample 141-861C-1H-CC. 7. Orbulina universa Orbigny, 1839; Sample 141-861C-15X-2, 6-10 cm. 8. Turborotalia quinqueloba (Natland, 1938); Sample 141-861C3H-CC. 9. Globorotalia scitula Brady, 1882; Sample 141-8612A-1H-1, 14-18 cm. 10-12. Truncorotalia truncatulinoides Orbigny, 1839; (10) Sample 141-862A-1H-1, 18-21 cm, (11-12) Sample 141-861C-1H-CC. 13-14. Globoconella inflata (Orbigny, 1839), (13) Sample 141-861C-4H-4, 109-114 cm, (14) Specimen covered with carbonate appositions, Sample 141-862A-1H-1, 18-21 cm. 15. Globorotalia crassaformis (Galloway and Wiesner, 1927); Sample 141-861C-16X-4, 30-35 cm. 16. Globigerinita glutinata (Egger, 1893) with two supplementary apertures on the spiral sutures of the final chamber as shown at tropical Globigerinita parkerae (Bermudez, 1961); Sample 141-861C-3H-2, 70-75 cm. 